\title{
EL SOL EN VIRGO: RITUAL Y EMBLEMÁTICA EN LAS FIESTAS DE BEATIFICACIÓN A SEBASTIÁN DE APARICIO EN LA CIUDAD DE MÉXICO
}

\author{
THE SUN IN VIRGO: RITUAL AND EMBLEMATIC \\ IN THE BEATIFICATION SOLEMNITIES TO \\ SEBASTIÁN DE APARICIO IN MEXICO CITY
}

SALVADOR LIRA

Centro de Actualización del Magisterio, Zacatecas

https://orcid.org/0000-0002-8055-6636

Recibido: 02/10/2020 Evaluado: 22/11/2021 Aprobado: 04/01/2022

Resumen: La imagen de fray Sebastián de Aparicio ha tenido una producción interesante desde el siglo XVI tanto en Puebla de los Ángeles, como en otros centros de la América Septentrional. En las solemnidades de su beatificación se generaron producciones artísticas con diversos intereses que, para el caso de la Ciudad de México, generó ciertos elementos de disconformidad en ritual y en motivos iconográficos. Desde una perspectiva histórica cultural, de arte y hermenéutica literaria, el objetivo del presente trabajo es explicar las rupturas y especificaciones de la celebración por la beatificación de fray Sebastián de Aparicio en la Ciudad de México en 1791 y presentar, con una primera lectura, el testimonio con emblemas al beato franciscano, atribuido a Bruno Larrañaga.

Palabras clave: Magnificencia y Poder, Emblemática y Literatura Novohispana. 
Abstract: The image of Sebastián de Aparicio has had an interesting production since the 16th century in Puebla de los Ángeles and in other centers of North America. On the solemnities of his beatification, artistic productions were generated with various interests that, in the case of Mexico City, generated certain elements of disagreement in ritual and in iconographic motifs. From a historical, cultural, art and literary hermeneutic perspective, the objective of this work is to explain the ruptures and specifications of the celebration for the beatification of fray Sebastián de Aparicio in Mexico City in 1791, with a first reading, the witness with emblems to blessed Franciscan, attributed to Bruno Larrañaga.

Key words: Magnificence and Power, Emblematic and Literature of New Spain

\section{INTRODUCCIÓN}

En el balance de las imágenes del periodo virreinal y su difusión es sin duda la de la Virgen de Guadalupe la que ha tenido mayor éxito, tanto en su poder integrador, como en su perduración. Y, si bien su consolidación en el siglo XVI respondió, sin entrar en detalles, quizá a un proyecto en específico de su tiempo y contexto, se pueden encontrar representaciones en diversos senderos, con otros fines. Es probable que de los más relevantes sea el de, en perspectiva, la conformación de una identidad novohispana, al proponérsele como un elemento, sobre todo en el siglo xviII, a la par de otras, como el águila mexica y los sellos reales.

Aunque, es menester precisar que, a lo largo del ciclo virreinal, así como en sus diferentes espacios, se propusieron múltiples imágenes en el intento de dar contención e identidad a ciertos grupos, no hay que olvidar que las imágenes devocionales, como los héroes, son sistemas de valores. Por referir ciertos casos, el de San Felipe de Jesús o el de fray San Diego que, dependiendo de las circunstancias, fueron propuestos con una serie de atributos -el águila o el nopal por mencionar algunos- en la integración de un nuevo ciclo novohispano, frente a otros que, en la región y periferia, hacen divergencia ante las obras de carácter poético y político.

Ahora bien, lejos de afirmar la consolidación de una imagen en toda la América Septentrional sin conflicto alguno, es preciso aclarar que muchas de ellas generaron una serie de divergencias y acciones. Esto, como causa o consecuencia, formó en perspectiva conflictos entre diversas instituciones, que entendían, en el contexto de la fiesta barroca, un código simbólico en las diferentes solemnidades con la colaboración entre el rito, la arquitectura 
efímera, la literatura emblemática y la representación de corporaciones y/o instituciones, que asistían a tales eventos.

Uno de los casos más singulares es la festividad por la beatificación de fray Sebastián de Aparicio en la Ciudad de México en febrero de 1791. Su imagen tuvo una presencia y consideración relevante fundamentalmente en Puebla de los Ángeles, dirimida bajo la centralidad de su eje catedralicio. Su interacción fuera de dicha jurisdicción eclesiástica, como es el caso en la capital novohispana, articuló desemejantes puntos de vista en la construcción y consolidación de una imagen que, por principio de cuentas, tenía disímiles usos e interpretaciones.

Los trabajos en torno a los procesos e iconografía de fray Sebastián de Aparicio si bien constan de elementos relevantes, aún no cuenta con un estudio en la dinámica de transformación antes, durante y después de su proceso de beatificación. ${ }^{1}$ Mucho menos se ha realizado un estudio que analice el caso de la imaginería de Sebastián de Aparicio fuera del territorio que constaba las delimitaciones de la catedral poblana, especialmente en la Ciudad de México o bien las producciones italianas.

Este asunto no es tema baladí porque a diferencia de los motivos y tipos iconográficos que se pudieran proponer, sobre todo en la dinámica poblana, fuera de tal responderá a desemejantes formulaciones. El caso de las festividades por la beatificación a fray Sebastián de Aparicio en la Ciudad de México es singular, en tanto la ausencia expresada por la Real Audiencia y, en consecuencia, el cabildo de la ciudad, así como la propuesta emblemática de Bruno Larrañaga en el aparato efímero.

El objetivo del presente trabajo, desde una perspectiva histórica, cultural, de arte y hermenéutica literaria, es explicar las rupturas y especificaciones de la celebración por la beatificación de fray Sebastián de Aparicio en la Ciudad de México en 1791. A su vez, realizar una primera lectura y explicar algunos emblemas del testimonio artístico al beato franciscano. Determinadas fiestas fueron una expresión en las que intervinieron las representaciones y atribuciones que no respondieron plenamente a las propuestas de la Real Audiencia o los cabildos de la catedral o la ciudad por las disconformidades de preeminencia entre instituciones. Antes, se vieron especificadas, a su vez por las marcas de estilo diseñadas en el tipo iconográfico y los emblemas atribuidos a Bruno Larrañaga. Con ello, la correlación entre la festividad y

1. El trabajo hasta el momento más íntegro al respecto es la tesis de Monserrat Báez. Su objetivo es la de identificar, entre las imágenes de Sebastián de Aparicio que se construyeron a partir de su vida y muerte, las referentes a su cuerpo difunto, primero como despojo corporal y después como reliquia taumaturga escenario de santidad. La hipótesis que plantea es que «la imagen de este cuerpo, al margen de las expresiones devocionales que generó, se trata en realidad de un actor relevante en el proceso apostólico, llegando inclusive -como se verá- a convertirse en el detonante de la apertura de la causa oficial, aunque alcanzando diferentes niveles de relevancia durante el mismo». MonserRAT ANDREA BÁez HeRnÁndez: De los despojos corporales a la reliquia y su imagen: el caso angelopolitano del beato Sebastián de Aparicio, Ciudad de México: Tesis de Maestría en Historia del Arte-UnAM, 2017, p.8. 
organización en dependencia con la conformación de la obra para la solemnidad, alejado de las particularidades de imagen que se elaboraron al beato en el espacio poblano.

El presente trabajo se divide en tres partes. En la primera se aborda de manera sucinta elementos iconográficos de la vida de fray Sebastián de Aparicio. En la segunda, se analizan los factores y puntos de la celebración en la Ciudad de México. En la última parte se realiza una primera lectura del manuscrito $E l$ sol en virgo..., atribuido a Bruno Larrañaga, en donde se explican algunos emblemas.

\section{Aspectos ICONOGRÁficos DEL BEATO}

Sebastián de Aparicio es uno de los casos de construcción de identidad y, en su accionar, la ubicación de un ideal de lo que pudiera reconocerse como un prototipo de hombre en el Nuevo Mundo. La propuesta de su imagen contrastaba con una formación y perfil de un «buen personaje» oriundo de la península ibérica. Nacido en La Gudiña, Orense en 1502, su paso a la Nueva España, entre el hecho histórico y la construcción simbólica de su vida, fue poco a poco considerándose con atribuciones axiológicas. Ragon argumenta:

A primera vista, la historia personal de Sebastián de Aparicio y la del progreso de su causa de beatificación son ricas en paradojas. Aunque nunca predicó la palabra divina, Sebastián de Aparicio fue el único franciscano de la provincia misionera del Santo Evangelio que obtuvo un título de santidad, mientras que su orden renunciaba a defender la causa de sus padres fundadores. En el momento en que los voceros de la Nueva España iban relacionando progresivamente la búsqueda de la canonización con la afirmación de la identidad criolla, tanto por su vida como por la sensibilidad religiosa que cristalizaba, Aparicio aparece como un personaje muy europeo. Finalmente, mientras que la Iglesia de la Contrarreforma buscaba santos que fueran ante todo modelos de virtudes cristianas, muy pocos elementos en la vida de Aparicio lo señalaban como tal. Esto nos indica que su beatificación respondía a expectativas muy distintas y revela otra dimensión de la Iglesia novohispana: Aparicio no es un santo clerical, su beatificación fue el resultado de la tremenda presión ejercida por la opinión pública, y su fama de santidad era fiel reflejo de las preocupaciones religiosas de los colonos españoles de la región de Puebla. ${ }^{2}$

2. Pierre Ragon: «Sebastián de Aparicio: un santo mediterráneo en el altiplano mexicano», Estudios de Historia Novohispana, año 36, volumen 60, enero-junio 2019, p. 18. 
Los detalles de la vida de Sebastián de Aparicio, que se relacionaron a su proceso de beatificación, fueron el de su oficio como carretonero y limosnero en la Ciudad de México y Zacatecas. Contuvo nupcias en dos ocasiones, aunque según los relatos siguió siendo virgen. Este hecho fue ratificado en un amplio razonamiento jurídico y teológico a posteriori por la Universidad de Salamanca y la Universidad de La Sorbona. ${ }^{3}$

Sebastián de Aparicio reunió una fortuna que, según varias descripciones, fue utilizada a fin de apoyar a los pobres. En San Francisco de Puebla murió recogiendo las limosnas para el sostenimiento del convento, recorriendo con su carreta la región poblana. De allí que uno de sus perfiles principales sea el de viajante, hasta la fecha.

Es relevante notar que el proceso de consolidación de su perfil pasó por distintas etapas. Su muerte el 25 de febrero de 1600 y su exhumación el 9 de julio de ese mismo año, en la observancia de su cuerpo -según las relaciones incorrupto-, motivaron una amplia devoción, del que poco a poco fueron solicitando su ascenso a los altares.

Se pueden observar algunas categorías en la construcción y consolidación de la imagen de fray Sebastián de Aparicio, previo a su beatificación. La primera, siguiendo a Monserrat Báez, ${ }^{4}$ fue una construcción literaria iniciada por fray de Torquemada en 1601. A partir de aquí, se encuentra un extenso acervo bibliográfico con descripciones de vida, en la que se observa la repetición de atributos; algunos de ellos en proyección de ciertos puntos y argumentos nuevos propios de su tiempo y contexto. La gran mayoría son de origen novohispano, aunque existen otras en distintos idiomas publicadas en Europa. ${ }^{5}$

A finales del siglo XVII es cuando se inicia el proceso de su construcción gráfica. Los atributos al beato más importantes serán las analogías con San Francisco, el espacio geográfico, el árbol milagroso, las carretas, el domar animales salvajes y la jícara. ${ }^{6}$ Respecto a este último, cabe mencionar el siguiente relato. En los últimos momentos de su vida, según diversas relaciones, el fraile pidió en una casa un poco de agua. Una moza se lo dio en un jarro, hecho por el cual fue reprendida por su ama y la obligó a tirarlo en un corral. Luego de su muerte, el ama fue a buscar la jarra, que estaba intacta y con una azucena creciendo, hecho interpretado como la pureza virginal del beato. ${ }^{7}$

3. Pareceres de las Universidades..., Salamanca: Universidad de Salamanca, 1720. BNE, Sede Recoletos, Signatura 2/67399(2).

4. BÁez Hernández: De los despojos..., p. 21.

5. Isidoro de SAn Miguel: Paraíso cultivado..., Nápoles: Estampería de Juan Vernuccio y Nicolas Layno, 1695; Paolo Mariani: Vita, e miracoli del venerabile servo di Dio fr. Sebastiano d'Apparisio..., Roma: Marc’Antonio \& Orazio Campana, 1696; y Nicolás Plumbensi, Opusculum vitae..., Roma: Ex Oficina Reverendae Camerae Apostolicae, 1696.

6. Báez Hernández: De los despojos..., p. 39.

7. Ibídem. 
De estos elementos iconográficos se observarán una serie de grabados y pinturas, dentro y fuera de la Nueva España. Se pueden encontrar tres constantes y puntos álgidos durante el siglo XVII y XVIII. Están aquellos en los que fray Sebastián de Aparicio tiene en su mano derecha una piedra para su mortificación y en la izquierda un rosario. Alrededor de él, relieves llenos con azucenas. Se encuentran otros en donde de una enorme azucena saldrá el beato en posición orante. ${ }^{8} \mathrm{Al}$ lado de él, en algunas ocasiones, se propondrán los motivos de la carreta, los animales domados o los motivos naturales y el árbol milagroso. Otras más harán relación a su cuerpo incorrupto (Fig. 1).

Aunque, para este estudio, es relevante hacer notar aquellas imágenes con características y atributos que tienen que ver con la formulación de imágenes por instituciones. En este sentido, retoma importancia que no se tenga en la Ciudad de México a través del cabildo catedralicio o la orden franciscana la propuesta de alguna imagen o atributo iconográfico, fuera de su logro de beatificación. Y a pesar de ello, de ejemplos notables hay, que permiten explicar tales devenires.

En la biografía Opusculum vitae... de Nicolás Plumbensi aparece uno de los grabados más interesantes. En la parte izquierda asoma, floreciendo de una azucena, fray Sebastián de Aparicio con la piedra de mortificación y el rosario. Se encuentra junto al motivo del árbol, sobre una carreta y un buey. Hasta aquí, todo el conjunto contrastaba con la imaginería del fraile. No obstante, el conjunto es aún más rico. En la parte inferior, se colocó al águila devorando a la serpiente, sobre un nopal, con todo el esplendor coronado. Detrás, una ciudad que, por la inscripción, se trata de Roma. En la parte derecha del grabado, América hincada ofreciendo un libro con la inscripción «Vita de V. S. D. F. Sebastian de Aparicio». Su postración es en la orilla de una costa, por la que una nave unifica dos territorios y, más allá, un sol amaneciendo. Arriba, el retrato de Inocencio XII con el sello papal y con el regio de Carlos II.

El grabado es una conjunción interesante de atributos. En suma, es notable no pensar en la referencia al emblema de Isidro de Sariñana en el Llanto del Occidente..., libro de exequias a Felipe IV, en donde por vez primera, bajo un sello por la Real Audiencia de México, se propuso a América revestida, adornada de huipil. En el centro, uniendo con Europa, el túmulo filipino y la nave con la noticia real, hecho que igualaba los reinos. En este caso, América propone la vida sin mácula del fraile y lo apunta con la izquierda, cual fruto ofrecido a la veneración del pontífice.

8. Véanse por ejemplo los grabados en: Fray Joseph Plancarte: Rezo devoto..., Ciudad de México: Imprenta de Mariano Zúñiga y Ontiveros, 1925; o en The life of the blessed Sebastian of Apparizio..., London: Thomas Richardson and Son, 1848. 


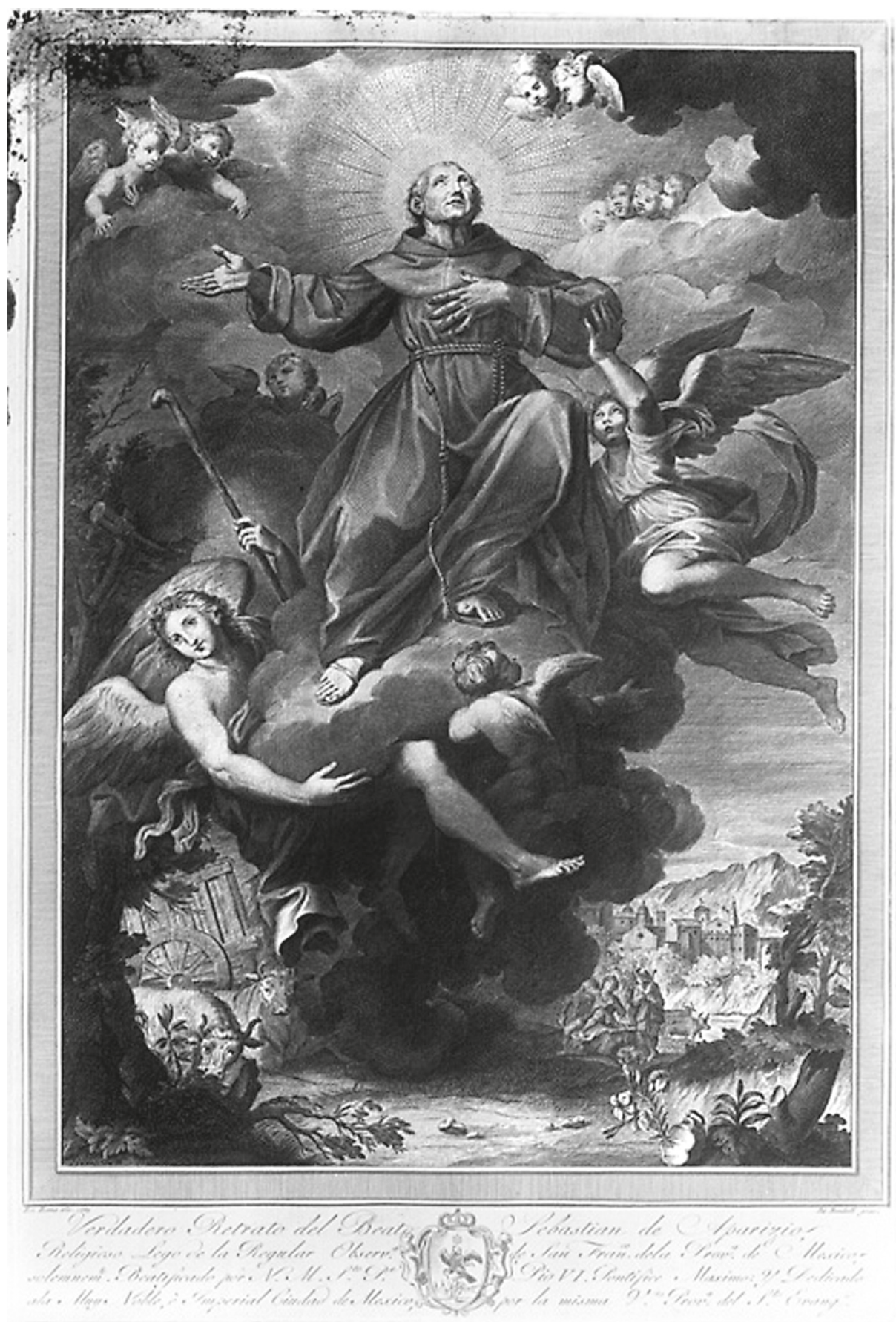

Fig. 1. Grabado de fray Sebastián de Aparicio por la Real Audiencia de México con motivo de su beatificación. Fotografía de Guillermo Kahlo, Fototeca Nacional, inaH, México. Véase en línea en el portal de la Mediateca INAH: https://mediateca.inah.gob.mx/islandora_74/ islandora/object/fotografia\%3A469052 
Esta reproducción es relevante, en tanto que el modelo de elaboración no fue la propia Real Audiencia o alguna institución del orbe novohispano. Por el contrario, se trató de una representación europea, que en perspectiva retomó elementos de significación y propuso la imagen del orbe. Cabe decir que, debajo de la mujer vestida de huipil, se colocó la inscripción de America Septentrionalis, de este modo dio atisbos al territorio novohispano, dejando de lado elementos característicos de Puebla de los Ángeles.

Sin embargo, tan notable fue la representación, como única en su modo y forma en la conjugación del beato con el águila mexica y la noble señora del orbe. Se tiene otra representación parecida, realizada por Pietro Leon Bombelli y Arnold Van Westerhout, justo en el momento de la beatificación. Aparece Sebastián de Aparicio ascendiendo al cielo, cargado por ángeles y querubines, entre árboles, azucenas y el espacio poblano. En la parte inferior, fuera del grabado, una inscripción y como centro el escudo del águila coronado encima de un nopal, devorando a la serpiente. $Y$, aunque se trate de un elemento integrador, cabe decir que bien es un grabado que trató de sintetizar un motivo por la ocasión, cual manera de pertenencia.

Es probable que, como punto dialógico a la imagen de Pietro Leon Bombelli y Arnold Van Westerhout, se halla elaborado, con referencias poblanas, el grabado de José de Nava en 1790. El beato está con sus atributos característicos. En la parte inferior, el esplendor del escudo de armas de Puebla de los Ángeles con una inscripción. ${ }^{9}$

Las imágenes poblanas van en la repetición y observancia de los motivos del árbol, los relieves geográficos, el rosario, la piedra de las mortificaciones, los animales domados y la jícara. A su vez, con tremenda fuerza, la construcción de su cuerpo incorrupto.

El lego franciscano [argumenta Monserrat Báez] como sujeto histórico vivió inmerso en una sociedad estamentaria regulada por instituciones que buscaron definir a través de sus normas la dimensión social y espiritual de su vida. Una de estas instituciones, la Iglesia, codificó la vida a través del cristianismo y su liturgia, regulando los conceptos de los fenómenos ligados a la existencia humana tanto del ámbito terrenal como del espiritual: el nacimiento y la muerte, la salvación y el pecado, el cielo y el infierno; siendo de nuestro especial interés el relativo al cuerpo, vehículo central del plan de salvación. Aparicio poseyó un cuerpo sujeto al concepto cristiano en sus dos realidades: materia perecedera y móvil de santidad; pero como miembro de una orden religiosa, también estuvo determinado por la visión de lo corpóreo que se tenía al interior de dicha corporación. Si bien el fenómeno del comportamiento prodigioso de los cadáveres de personajes muertos con fama de santidad no resulta un acontecimiento único en la Nueva España ya

9. Joseph Carmona: Panegírico sagrado del B. Sebastián de Aparicio..., Puebla de los Ángeles: Oficina del Real Seminario Palafoxiano, 1792, p. sn. 
que se tienen noticias de venerables que se comportaron de forma similar, la manera en que el cuerpo de Sebastián de Aparicio se convirtió en el móvil que detonó la búsqueda de la causa de santidad y que posteriormente se conservó a manera de prueba durante el proceso, lo convierten en un caso atípico en el que vale la pena detenerse. ${ }^{10}$

Hasta aquí, un breve recuento de las construcciones iconográficas de fray Sebastián de Aparicio. Cierto es que aún existen otros elementos de construcción, como en los territorios italianos. Se tienen noticias de que muchos atributos fueron elaborados en otros espacios, por ejemplo los de Nicolás Gadini y el legajo resguardado en la Biblioteca Nacional de México, en donde aparecen otros nombres de autores. ${ }^{11}$ Sin embargo, con todo ello, los atributos del franciscano irán entre su perfil de carretonero, limosnero y hombre de pureza virginal. ${ }^{12}$

\section{La beatificación de Sebastián de Aparicio en la Catedral DE MÉXICO}

La festividad de la beatificación de Sebastián de Aparicio en la Ciudad de México es un caso de extrema observancia o, mejor dicho, la formulación de poderes y resguardo del decoro en pleno siglo xviII. Su interés radica por la declarada ausencia de la Real Audiencia, encabezada por el virrey Juan Vicente de Güemes, ante lo que pudiera considerarse como uno de los momentos más álgidos del ciclo novohispano, por acercar a un previo escaño de santidad a un hombre que, en perspectiva simbólica, forjó su carrera religiosa en los territorios novohispanos. Y, frente a la ausencia de la máxima autoridad novohispana, el secundo generalizado por la totalidad del cabildo de la Ciudad de México.

Aunque es poca la documentación que se ha podido recabar al respecto; se puede construir y constituir que, en lo general, el asunto dispuesto y las problemáticas fueron de orden de preeminencia. La beatificación de

10. Báez Hernández: De los despojos..., p. 146.

11. «Memoria de los diseños por algunos pintores...», 1623, Clasificación 124/1623.4, BNM.

12. En las solemnidades por la beatificación en Guadalajara, se hizo un aparato con una carreta. En la Gaceta de México aparece una descripción: «Se puso una Carreta, máquina de cohetes con todo su atavío de bueyes, timón y ruedas, que por unas cuerdas voló desde lo alto de la Torre, pasando por todo el Cementerio hasta la Torre de la Iglesia de San Antonio: encima de la Carreta se dejaba ver un Retablo del Bienaventurado Aparicio, adornado de luces que no dejaban cosa alguna por registrar en el lienzo, ni por admirar en la Imagen; y esto aparte de un árbol de fuego, que asimismo dio que admirar mucho al concurso». Gazeta de México, 1791-06-07, pp- 329-331, consúltese en: http://www.hndm.unam.mx/ index.php/es/. 
Sebastián de Aparicio, con la colaboración y gestiones de Mateo Ximénez, ${ }^{13}$ encargado del proceso en Roma, amplían dudas y procesos de un conflicto mayor, que no es más que el ajuste de cuentas y la observancia de poderes en un momento en reordenación, posiblemente por las nuevas dinámicas que generaron las Reformas Borbónicas años atrás. El tema se agrava si se toman en cuenta las dificultades por las que pasó la orden para que el fraile llegara al título de beato. ${ }^{14}$ En torno al conflicto, se suscitan varios cuestionamientos: ¿por qué la ausencia?, ¿qué elementos desencadenaron la no participación de la Real Audiencia y del cabildo de la ciudad?, ¿cómo interpretar los gestos rituales y artísticos como sellos característicos de, en general, el espacio poblano frente al circuito de poder por la catedral metropolitana, la capital novohispana y el espacio del convento de San Francisco en México?

Ante lo que se ha considerado por la historiografía, el fasto de celebración por la beatificación en la ciudad de México fue amplio y con enormes tintes. ${ }^{15}$ Además de lo registrado por el cabildo de la Ciudad de México, la biblioteca de la catedral metropolitana o la Biblioteca Nacional de México, es preciso señalar el documento El Sol en Virgo... (Fig. 2) que no es más que una descripción manuscrita de los emblemas y algunos poemas realizados para la beatificación en el convento de San Francisco en la Ciudad de México, para el día 25 de febrero de 1791. Tal documento demuestra el nivel de fasto que se elaboró al respecto.

13. Mateo Ximénez sacó a la luz un documento en honor a Sebastián de Aparicio. Mateo XiménEz: Compendio della vita del Beato Sebastiano D’Apparizio..., Roma: Estampería Salomoni, 1789.

14. «La temporalidad de la documentación permitió identificar como fechas extremas el 25 de febrero de 1600, muerte de Aparicio y el 17 de mayo de 1789, día de la declaración de su beatitud. Otras fechas importantes son 1603, momento en que el rey Felipe III solicita al prelado angelopolitano Diego Romano las primeras informaciones de Aparicio; 1628, año en que arribó el Rótulo o las letras remisoriales y compulsoriales que dieron inicio a la apertura de la causa en Roma; y el 2 de mayo de 1768, cuando el lego fue declarado siervo de Dios por el papa Clemente XIII». BÁEz Hernández: De los despojos..., p. 8.

15. Cfr. «La noticia que, como se mencionó, llegó en 1790 a Nueva España, fue celebrada en la Ciudad de México con "general repique y continuadas salvas de cohetes y bombas" aunque sin mucho adorno, probablemente por estar ocupada la ciudad en celebrar las honras fúnebres de Carlos III, muerto el 14 de diciembre de 1788. En Puebla se efectuaron honras a partir del 16 de octubre, y durante 12 días, todas las religiones rindieron función solemne: el primer día cantó misa Pontifical el recién erigido obispo Salvador Biempica y Sotomayor y en los días sucesivos el cabildo Catedralicio, seguido por las comunidades de Santo Domingo, San Agustín, El Carmen, La Merced, Belén, San Felipe Neri, San Antonio, San Francisco, la Nación Gallega y el gremio de plateros. En días posteriores también se unieron otros gremios de la ciudad y el cabildo de Naturales». Monserrat Andrea Báez Hernández: «El proceso apostólico de Sebastián de Aparicio patrono no jurado de la ciudad de los Ángeles», Cuextlaxcoapan Revista del Centro Histórico de la ciudad de Puebla, año 4, no. 14, verano 2018, p. 20. Por ejemplo, a propósito del certamen del siglo XVII no impreso de la beatificación de San Pedro Nolasco, fray Fernando Álvarez inscribía en el manuscrito: « ¿ $\mathrm{Q}^{\mathrm{e}}$ vergüenza $\mathrm{p}^{\mathrm{a}}$ nosotros será el $\mathrm{q}^{\mathrm{e}}$, siendo lego este Sto, y no siendo patriarcha (como lo es N. P. S. Nolasco) salga impressas $\mathrm{p}^{\mathrm{r}}$ sus religiosos $[\mathrm{sic}]$, los quales se mantienen de la probidencia, sus obsequiosas funciones?». Citado en JessiCA C. LoCKE: Es grande el poder de la poesía, Madrid: Iberoamericana-Vervuert, 2019, p. 119. 


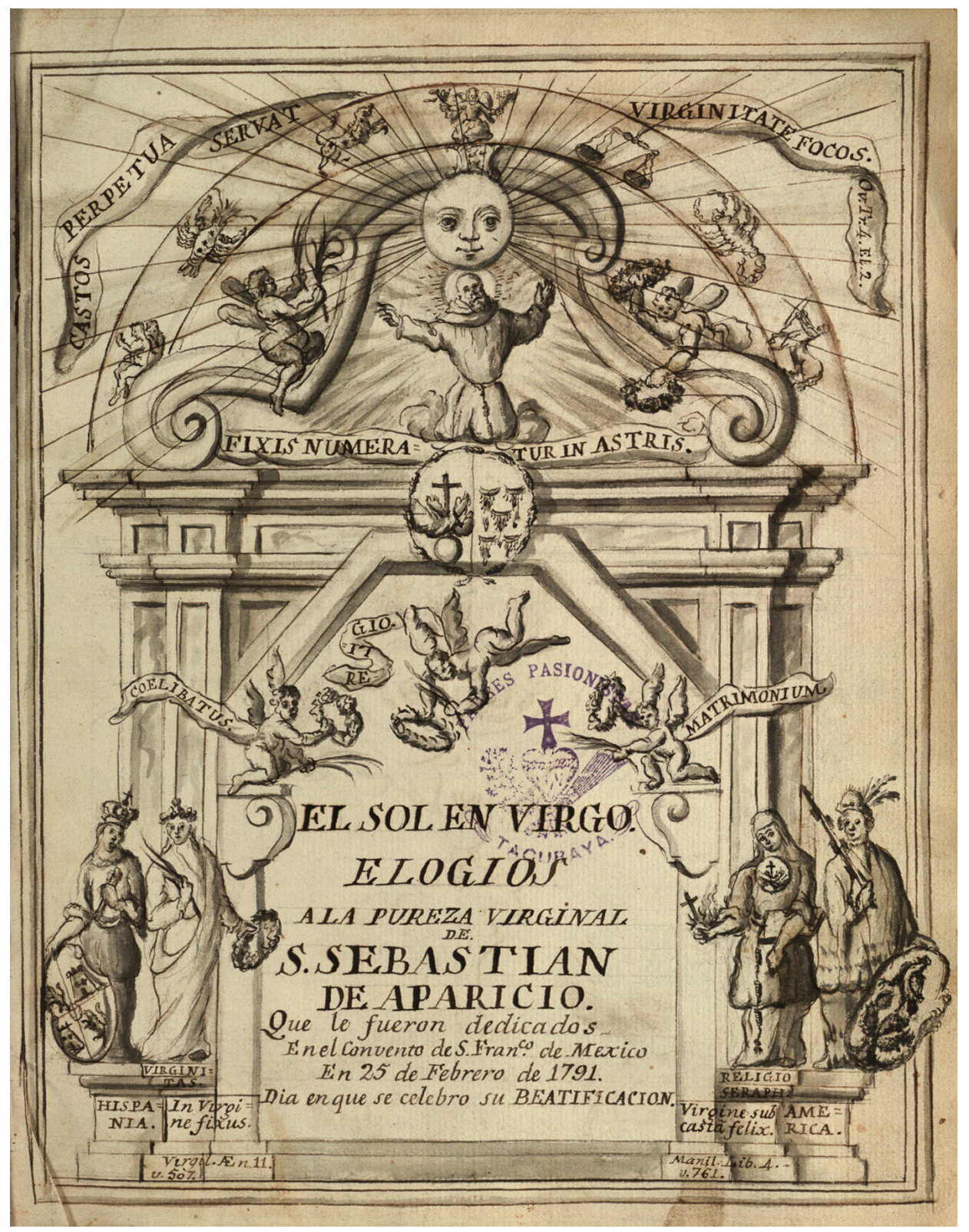

Fig. 2. Portada de El sol en virgo... cuadernillo por las fiestas de beatificación a Sebastián de Aparicio en la Ciudad de México, AHPSEm-BX4705 A6.556.5 1791, AHPSem 
Lo que es menester dilucidar son las condicionantes de la producción y el porqué, en todo caso los cabildos de la ciudad y catedral o mucho menos la Real Audiencia hicieron alarde y efectivos fastos por la beatificación de Sebastián de Aparicio, siendo que, en perspectiva, se prestaban tales condiciones. Por otro lado, las manifestaciones artísticas y literarias distan mucho de los motivos propuestos en el espacio poblano.

Todo apunta a que la ausencia fue por una política «revisionista» y de restitución, por parte del virrey. El proceso es mucho más amplio. Se debe decir que, en el momento en que se llegó la noticia de la beatificación del fraile, coincidió con el también aviso de la muerte del monarca Carlos III y el posterior relevo entre virreyes. Para ese momento, se encontraba aún en el mando Manuel Antonio Flórez Maldonado. Haciendo un recuento breve, las exequias a Carlos III se solemnizaron antes de la jura a Carlos IV, a diferencia de lo que estipulado en todo el ciclo virreinal. La vigilia y las vísperas, a voto consultivo por la sala del Real Acuerdo, se llevaron a cabo el 26 y 27 de mayo de 1789, como lo consta el impreso de exequias. ${ }^{16}$

Las exequias a Carlos III en perspectiva rompieron ciertas condicionantes en la mayoría de los puntos y ciudades del orden virreinal anteriormente realizados. Los diseños de la pira fueron de orden neoclásico ${ }^{17} \mathrm{y}$, por ejemplo, el de la catedral metropolitana se realizó sin revestimiento alguno de emblemas. $Y$ aunque en el protocolo de exequias se siguieron como se hizo anteriormente, hubo algunos de «nuevo orden», como el concepto de «relación historiada» o bien la simplificación de algunas etiquetas.

Sin embargo, el asunto de mayor interés fue la posición de ciertas figuras, que a la llegada del II conde de Revillagigedo se buscó respetar. Como es bien sabido, las Reformas Borbónicas plantearon una nueva figura jurídica, al mando de una división político-fiscal: el intendente. Esto, en el cabildo de la catedral y la ciudad de México configuró algunos conflictos que, en efecto, para la realización del ritual de vísperas y vigilia, fue resuelto por el organigrama superior en tanto que el virrey, como cabeza de la Real Audiencia, sobreponía su figura como representación del monarca y por lo tanto la custodia de las insignias reales. No obstante, en otros espacios de la Nueva España, por conflicto de preeminencia y decoro, múltiples figuras lucharon

16. Reales exequias celebradas en la santa iglesia catedral..., Ciudad de México: Imprenta de Felipe de Zúñiga y Ontiveros, 1790.

17. Véase: Francisco de la Maza: Las piras funerarias en la Historia y en el Arte de México. Grabados, Litografías y Documentos del siglo XVI al XIX, Ciudad de México: unAM-Anales del Instituto de Investigaciones Estéticas, 1946; VÍCTOR Mínguez: Los reyes distantes: imágenes del poder en el México virreinal. Castelló de la Plana: Univesistat Jaume I, 1995; Víctor Mínguez, Juan Chiva Beltrán, Pablo González Torne e InMaculada Rodríguez Moya (coords.): La fiesta barroca. Los virreinatos americanos (1560-1808), Castelló de la Plana: Publicacions de la Universitat Jaime I, 2012; SALVADOR LIRA: «De la alegoría a la virtud: exequias reales a Carlos III en la Nueva España», Revista Dieciocho, número 44, fall 2, 2021, pp. 279- 308. 
por mantener o abrogar su posición en el ritual, en tanto código de observancia plena de los poderes y la jerarquía.

El relevo del mando virreinal entre Manuel Antonio Flórez Maldonado y el II conde de Revillagigedo se dio entre la observancia de llevar a cabo dos rituales: la jura real a Carlos IV y la entrada triunfal del nuevo virrey. El lapsus tempus fue de al menos unos meses y, entre esa situación, también lo estaba la organización del fasto al beato.

De este modo, la Real Audiencia de México y el cabildo de la ciudad iniciaron con la consideración de «proyectos» para tales solemnidades. Se tiene el registro del proyecto de Ignacio de Castera, signado el 12 de julio de 1789. Cabe decir que este tipo de planes eran presentados ante los comisarios para su discusión en el proceso-protocolo jurídico ritual. Se trata de un manuscrito con más de 20 puntos, junto a varios dibujos de las diferentes arquitecturas festivas. Se puede resumir en aspectos rituales, elementos artísticos, economía, así como la edificación de aparatos ya no efímeros. Tales dan pauta a un cambio de pensamiento, ya que buscaba unificar la jura al monarca y la entrada triunfal del virrey, además de querer reunir celebraciones con otros organismos, modelo de pensamiento con miras hacia la Modernidad. ${ }^{18}$

La relevancia de este documento es para observar una proyección y en perspectiva la decisión del virrey de mantener algunas festividades para no alterar «formalidades». Así, el virrey II conde de Revillagigedo no aceptó la propuesta, dado que diferentes instituciones, como la Real Universidad, el Gremio de Plateros o la propia Real Audiencia se veían afectadas en la ostentación de sus títulos y obras, ante una idea unificadora. De la realización, se sabe que estas tres instituciones efectuaron lo conveniente. ${ }^{19}$ La real Audiencia lo hizo el 28 de diciembre de 1789, con la escritura de emblemas por Bruno Larrañaga, mientras que las otras festividades se dieron durante $1790 . .^{20}$

Durante ese proceso, se dieron también las discusiones entre la elaboración del fasto del beato. ${ }^{21}$ Las fechas estipuladas fueron del 24 al 27 de

18. Para un análisis más extenso de este caso, véase: Salvador Lira y María Isabel Terán Elizondo: «Las juras a Carlos IV en la Nueva España y el proyecto de Ignacio de Castera», en prensa, 2021.

19. Juan Chiva Beltrán destaca la polémica por la búsqueda de ahorros en el fasto de la entrada virreinal del conde de Revillagigedo. Véase: JuAn Chiva Beltrán: El triunfo del virrey. Glorias novohispanas: origen, apogeo y ocaso de la entrada virreinal, Castellón de la Plana: Universitat Jaume I, 2012, pp. 236-237.

20. JuAn de Borja: Breve relación de las funciones..., Ciudad de México: Imprenta de Felipe de Zúñiga y Ontiveros, 1790 y Obras de elocuencia y poesía premiadas por la Real Universidad de México..., Ciudad de México: Imprenta de Felipe de Zúñiga y Ontiveros, 1791. En febrero de 1791, Bruno Larrañaga solicitó le regresaran un cuadernillo con los versos puestos en el tablado de jura a Carlos IV. El cuadernillo, de momento, está perdido. Véase: Actas de Cabildo, Libro 17, AHCM, pp. sn.

21. De las primeras noticias de una solemnidad por la beatificación de fray Sebastián de Aparicio en la Ciudad de México se sitúan justo en el proceso antedicho, con repique y salvas el 4 de noviembre. Por la mañana se habían celebrado las honras por el inicio de los festejos al cumpleaños de Carlos IV. Véase: Gazeta de México, 1789-11-10, p. 420, consúltese en: http://www.hndm.unam.mx/index.php/es/. 
febrero de 1791 en la iglesia del convento del San Francisco, con el clímax celebratorio el 25 en conmemoración de la muerte del beato y el 27, su cierre. De este asunto, se generó una confusión por preeminencia. El obispo de Puebla, Salvador Biempica y Sotomayor, recién nombrado, ${ }^{22}$ llevaría a cabo las solemnidades el 27, lo que quizá haya sido el mayor malestar entre las autoridades en la Ciudad de México, ya que restaba a su poder y dignidad.

El intendente corregidor de la Ciudad de México Bernando Bonavía recibió, con el cabildo de la ciudad, el 18 de febrero de 1791 a un convite de padres provinciales franciscanos y dominicos para la asistencia a la primera función del beato y se aceptó la participación. No obstante, a un día previo, el 23 de febrero, se expresa en las actas de cabildo una reunión entre el intendente corregidor y el virrey. Allí, se da cuenta que ni la Real Audiencia, ni su presidencia asistirían a las funciones, por lo que ahí se determinó que, por «formalidad», tampoco lo haría el cabildo. Dado que no se contestó por escrito la resolución de la primera visita, se hizo un documento de respuesta negativa. ${ }^{23}$

En este sentido, se da cuenta que la rispidez fue entre el virrey y la forma de organización, dado que la negativa refiere a los atributos por «formalidad», que en este caso refieren a la manera de llevar rituales y la preeminencia de instituciones. Cabe decir que el obispo Salvador Biempica en efecto celebró las solemnidades y, aunque de momento no se tienen noticias, cabe la posibilidad de que los cuerpos institucionales de Puebla de los Ángeles hayan tenido participación, en cierto modo, protagónico. Con ello, acrecentando una rivalidad por distinción de tiempo entrambas ciudades. El sermón de Quintela generó un guiño sobre este conflicto. Al momento de explicar la humildad de fray Sebastián de Aparicio, en una forma de analogía, distingue esta cualidad y la igualdad entre el obispo de Puebla y el virrey:

Aquella distinción, que la humana Política ha hecho de títulos y tratamientos, para distinguir las personas, no la conocía su admirable simplicidad: y satisfecho, de que tratando a Dios con el respeto más rendido, bastaba tratar a los hombres de cualquiera manera, a todos los trataba de vos. Es verdad que respetaba las Dignidades, y a todos se rendía con humildad cristiana; mas en los títulos de tratamiento no distinguía él ni Excelencia, ni Señorías. De vos trataba a los Virreyes, de vos trataba a los Obispos; bien que los Obispos y los Virreyes, muy lejos de ofenderse, quedaban antes edificados de su sencillez columbina. Admiráronse de ella los Gaspares de Zúñiga Virreyes de esta Nueva España, y edificáronse con ello los Ilustrísimos Diegos Romanos Obispos de la Puebla. ${ }^{24}$

22. Juan Pablo Salazar Andreu: «Algunos aspectos políticos y jurídicos del obispo de Puebla Salvador Biempica y Sotomayor (1790-1802)», Anuario Mexicano de Historia del Derecho, vol. XVII, 2005, pp. 83-96.

23. Actas de Cabildo, Libro 17, АнСм, pp. sn. La única participación fue la de iluminar las casas capitulares víspera y día. Véase: Ayuntamiento, Patronato, 3604, exp. 22, AнCM.0

24. Agustín de Quintela: La sencillez..., Ciudad de México: Imprenta de Mariano Joseph de Zúñiga y Ontiveros, 1791, p. 6. 


\section{FXX VIRGTLIO MARONK}

Romae merito (1)PARTHENIAS appellato VATES, Lati= norumquo Vatum facile Principe: (2) castitatis amanti= simo, ac pudicitice: in laudem integritatis virginalis,Angelicae que puritatis: in APOTHEOSIS celebritatem BM̆̈i. SEBAASTLANI DEE APARICIO, desumptus

\section{CENTO.}

Salve Sancte Pater, maignem et memorabile nomen, As 5.80.04.94 Felix heu, niminom felixe" claxissime "Yxatex. Salve sanctefatex; quo non pxaestantiox altew Eg gregiusgue animi: famam gri truminat ts tris Insignis fietate, et sexvartissimus acgui

Sobilis et farra multis' memoxatzas in oxis. Vietor havd ulli vetexium vixture (5) secundues. 2.4.65\% 85.495 5.25.80.06.164 d11.41701.291 Q.1.14.22.4.27. $\therefore$ ar.564. Q 10.740 .11 .441 . (1) Parthenitws à Laxthenos, Gxece Vingo. (2) Quramgraan de saxone "f fama est libidinis pron ioxis in puevos frisse; "ssed boni ita eum puexos amase putavexunt, ket wocka "yter Alcibiadem, ef $\Psi$ lato wus puewo.... Invitatus qui$"$ dem a l'axio ad communionem muliciás: upese pex= "finacissime xecusavit. Cetcra sane vita et oxe et axi= 31 mo tam proburn. fuisse contat, us seapoli Partheninss mvalop appellazetzex. Donat. in epar vita. (3) Hispani= ce: Frayle. (4) Cum ab omnibus texme Guepae tcademïr quaesitum foxet: An Pyrausta actus hexoic vixtutis pex: fecisset emel atgue ivexion maximonizem contratuendo cum proposits vexuandi, exemple S. Joseph vinginitatem: idcixco pex oxben sanctitatis ejus fama vrilgata est..... (5) Conjuger aligut invenit wunt vixgines: veaum

Fig. 3. Primera página del poema centón a Sebastián de Aparicio con referencias de Virgilio, AHPSEM-BX4705 A6.556.5 1791, AHPSEM 
La ausencia de la Real Audiencia como máxima autoridad novohispana ante la beatificación de fray Sebastián de Aparicio es notable. No se publicaron los fastos, salvo el sermón de Agustín de Quintela. Se cuenta únicamente con breves narraciones en la Gaceta de México. ${ }^{25}$ Ahí, se sabe que el 24 y 25 de febrero se llevó en procesión la efigie del beato de la Catedral a la iglesia de San Francisco, acompañado por diversas órdenes y religiones, cerrado por el Cabildo Catedral. Con una iglesia adornada, se hicieron las vísperas cantadas que terminaron ya por la noche. Hubo también un elogio por fray Joseph Olmedo, catedrático de la Real Universidad, con la ceremonia por el arzobispo el 26. El cierre ritual lo hizo el obispo poblano con el sermón de Quintela.

\section{Los emblemas a fray Sebastián de Aparicio}

El único testimonio de un artefacto artístico literario en torno a las fiestas por la beatificación de fray Sebastián de Aparicio es El sol en virgo... (Fig. 2). ${ }^{26}$ Se trata de un manuscrito de 67 páginas no numeradas, de 30 centímetros, sin el nombre del escritor o del dibujante, hasta ahora inédito. El testimonio está compuesto de tres partes: la primera muestra las inscripciones y emblemas en el artefacto que se elaboró para la celebración; la segunda un poema centón con las obras de Virgilio (Fig. 3) y la tercera es una recopilación de poemas «jocoserios». Se ha dicho que no tiene el nombre del relator o del autor de los emblemas, sin embargo, lo atribuimos a Bruno Larrañaga, ${ }^{27}$ en principio, porque es al único escritor que se le paga en las fiestas de beatifica-

25. Véase: Gazeta de México, 1791-03-15, pp. 277-280, consúltese en: http://www.hndm.unam.mx/ index.php/es/.

26. El documento se encuentra en el Archivo Histórico de la Provincia Franciscana del Santo Evangelio de México. Clasificación: AHPsem-BX4705 A6.556.5 1791, ahpsem. Recientemente, se digitalizó la totalidad del documento, mismo que se puede consultar en la siguiente liga: http://catarina. udlap.mx/xmLibris/projects/biblioteca_franciscana/book?key=book_ca89eb.xml. Se cuenta con otra brevísima descripción de emblemas en Guadalajara, en una relación impresa en la Gaceta de México. Lamentablemente, la relación íntegra no se ha podido encontrar. Según el breve testimonio, fue un arco de lienzo pintado con varios «jeroglíficos, símbolos y emblemas». Los emblemas referidos por la Gaceta fueron: un león reposado en un campo verde, con una corona por serpiente; león pisando la tierra y su cuerpo sobre el mar; un león erizado en un campo azul, resguardando con sus garras la cruz y la espada; un león feroz, defendiéndose de un cazador, agazapado en las orillas del mar; y en el centro, un león en una gruta, alentando a sus cachorros. Véase, Gazeta de México, 1791-06-07, pp. 329-331, consúltese en: http://www.hndm.unam.mx/index.php/es/.

27. María Isabel Terán Elizondo es quien más ha analizado su figura. Véase: MARÍA IsABEL TERÁN Elizondo: Orígenes de la crítica literaria en México: La polémica entre Alzate y Larrañaga, Zacatecas: uaz - El Colegio de Michoacán, 2001; y María Isabel Terán Elizondo: Dos poetas admiradores de Virgilio. La obra literaria de Bruno Francisco y José Rafael Larrañaga, Ciudad de México: Factoría Ediciones - UAZ - La Serpiente Emplumada, 2020. 
ción ${ }^{28}$ y también por su caligrafía, sobre todo en la del centón final. Aunque, son quizás las marcas de estilo y las referencias a determinadas obras las que permiten dar crédito de realización..$^{29} \mathrm{Al}$ parecer se elaboró para una futura publicación por los fastos del 25 de febrero en el convento de San Francisco. $^{30}$

Hay que señalar que la primera parte no muestra una descripción de cómo se elaboró el artefacto en sus dimensiones o de la relación ritual. No obstante, tiene un enorme interés para los estudios de la emblemática, debido a que reproduce a cabalidad sus partes: pictura, mote suscriptio. Aparecen 28 emblemas (Fig. 4), siendo los dos primeros (Fig. 5) una configuración de tres lienzos o escenas con tres motes y una suscriptio. Los demás (Fig. 6 y Fig. 7) se componen por una página para la pictura y el mote con una breve explicación y en la siguiente la suscriptio. En el dibujo, en la parte superior, se muestra el mote, por lo que es probable que sea tal cual y como aparecieron en el aparato festivo.

La gran mayoría de los emblemas no corresponden en perspectiva a los atributos característicos del beato, ni los elaborados en el espacio poblano. Únicamente en la «Fachada del Cuaderno» aparece una enorme jícara con una azucena en lo alto, mientras que de soporte un dibujo del beato tirando dos bueyes y caminando hacia un templo.

En el manuscrito, la propuesta se funda en la propia tradición emblemática, con la asociación del tema de la pureza y la virginidad del fraile. En la portada, a manera de fachada arquitectónica, se impone el tipo iconográfico de todo el conjunto (Fig. 2): el sol en el signo de Virgo en alegoría con fray Sebastián de Aparicio y la castidad. El beato aparece hincado sobre un frontispicio y debajo de un sol luminoso, que va pasando en un relieve cósmico; formulación astral que se puede visibilizar en dos grabados de las obras de Redelio y Dor-

28. Cuenta y razón de todo lo gastado por el padre Galindo en las fiestas de la beatificación de fray Sebastián de Aparicio realizadas en Puebla y México. Clasificación Local: 126/1641.5, BNM.

29. Por poner solo un ejemplo, en la jura a Fernando VII en 1808, descrita por el zacatecano se encuentra una misma estructura de organización textual: descripción de los emblemas, un poema epigramático virgiliano y finalmente una serie de poemas. Por otro lado, muchos emblemas de los tablados se repiten en forma por lo que inclusive se puede llegar a pensar que algunas pinturas del beato fueron utilizadas para la aclamación. Fundamentalmente son el sol con estrellas; el sol alumbrando al orbe y a la tierra; el farol de cristal resguardando una vela de los vientos; el sol en oriente ahuyentando aves nocturnas; el panal y las abejas; el heliotropo mirando al sol; la concha con la perla sobre las aguas; o las estrellas de noche. Cabe decir que, junto a su hermano Rafael Larrañaga, en reiteradas ocasiones propusieron al sol como un elemento para homenajear a personajes en varias obras. Véase: JosÉ MANUEL Trujillo Diosdado: Ritual politico y emblemática novohispana. Representaciones del héroe en la entrada triunfal virreinal, Querétaro: Tesis de Maestría en Estudios Históricos, UAQ, 2017.

30. Es probable que sea la que refiere la Gaceta de México: «La Relación que intenta publicar de estas fiestas la Seráfica Provincia llenará los deseos de los que aguardan la noticia circunstanciada de ellas, respecto a no ser posible reducirla a los límites de la Gaceta; pero habiendo llegado a nuestras manos una Estampa Romana de este esclarecido Héroe, a cuyo pie se halla un Elogio Compendio de su portentosa Vida, nos ha parecido insertarlo en esta, para que puedan formar alguna idea de su eximia santidad de las Personas que no hubieren leído alguno de los libros que tratan de ella». Gazeta de México, 1791-03-15, p. 279, consúltese en: http://www.hndm.unam.mx/index.php/es/. 
nn. ${ }^{31}$ Debajo de él, el escudo de la orden de San Francisco con algunos ángeles con laureles. Sobre las columnas cuatro doncellas con proporciones de Cesare Ripa: la Virginidad aunque con laurel y corona en ambas manos, así como la Religión con el libro de la ley, el fuego y la cruz, sin embargo, vestida de atributos franciscanos, con el escudo en el centro y el cordón con nudos. Las otras dos estatuas son más interesantes aún, en el lado izquierdo Hispania o España, vestida con los atributos de Europa, según la Iconología, y América, siguiendo el modelo que se instauró en el Llanto del Occidente... de Isidro de Sariñana y también recuperada en el libro de Nicolás Plumbesi (Fig. 1). Estas dos últimas sostienen dos escudos de armas, el de Castilla, así como el del águila y la serpiente encima de un nopal. Tal será la única representación característica de la Ciudad de México de todo este conjunto, utilizada en otros espacios por la Real Audiencia o bien los cabildos de la ciudad o de la catedral, también equiparable a la portada del libro impreso en Roma. ${ }^{32}$

Destáquense ahora los siguientes emblemas. ${ }^{33}$ Los dos primeros dibujos del manuscrito son representaciones de pinturas emblemas (Fig. 5). Su elaboración es la postura de tres episodios, con motes, que se anclan a un poema. Esta forma es en cierto modo representativa de pinturas de ciclos franciscanos elaborados en el siglo XVIII, que en un solo emblema lienzo fueran reproducidos varios episodios, por ejemplo, los del convento de Guadalupe en Zacatecas o bien en la iglesia en donde se encuentran los restos de fray Sebastián de Aparicio en Puebla de los Ángeles. ${ }^{34}$ No obstante, es una cuestión de forma, ya que en contenido, como se ha dicho, no se corresponden a los motivos del beato en el espacio poblano o inclusive a alguna alusión de la vida de San Francisco. De hecho, aparece una interesante pictura de un impresor de estampas que trabaja en su tórculo, alejado de la iconografía atribuida en sí al beato. ${ }^{35}$ Lo mismo sucede con los emblemas subsecuentes, de carácter astral en Virgo, en función de la virginidad del beato.

31. A. C. Redelio: Elogia Mariana..., Augsburg: Martino Engelbrecht Chalcographo, 1732 y Fr ANCISCO Xavier Dornn: Letanía Lauretana..., Valencia: Imprenta de la viuda de Joseph de Orga, 1768.

32. Salvador lira y María Isabel Terán Elizondo: «Non fecit taliter omni nationi: los emblemas de la identidad criolla novohispana en expresiones de lealtad a la monarquía de los Austrias menores», José Julio García Arranz y Pedro Germano Leal (eds.): Jeroglíficos en la Edad Moderna. Nuevas aproximaciones a un fenómeno intercultural, Coruña: SIELAE, 2020, pp. 331-368.

33. Queda para futuros trabajos el análisis pormenorizado de cada uno de los emblemas del manuscrito.

34. Algunos ejemplos aparecen en: Báez Hernández: «El proceso apostólico...». Otros ejemplos se pueden observar en Leonardo Aguado: Vida del beato Sebastián de Aparicio, Ciudad de México: Secretaría del Arzobispado de México, 1947.

35. Mariana Garone Granvier refiere que para el caso americano únicamente se tienen dos ejemplos de grabados o dibujos de impresores: una en las exequias a Carlos II en el Perú de 1701 con la leyenda «Retrato de José de Contreras en su imprenta» y la otra en Puebla de los Ángeles de 1788 de la ampliación de la imprenta de Pedro de la Rosa. Esta es, por tanto, la tercera manifestación de un impresor, aunque no se indica el nombre. Véase: MARINA Garone GranviER: «Imprenta y libro antiguo. Consideraciones para el estudio material de la literatura novohispana», en Jessica C. Locke; Ana Castaño y Jorge Gutiérrez Reyna (coords.): Historia de las literaturas en México. Siglos XVI al XVIII, Tomo 1: El primer siglo de las letras novohispanas (1519-1624), Ciudad de México: unAM, 2021, pp. 3-40. 


\begin{tabular}{|c|c|c|c|c|}
\hline \multicolumn{5}{|c|}{ EMBLEMAS EN APARATO EFÍMERO A FRAY SEBASTIÁN DE APARICIO EN EL SOL EN VIRGO... } \\
\hline No. & ALEGORÍA & $\begin{array}{ll}\text { TIPO } & \text { DE } \\
\text { POEMA } & \\
\end{array}$ & IDIOMA & MоTE \\
\hline 1 & La mujer de Putifar con el patriarca Joseph & Soneto & Español & $\begin{array}{l}\text { "Nequaquam acquiescens operi } \\
\text { nefario... fuget et egressus est foras" }\end{array}$ \\
\hline 2 & $\begin{array}{l}\text { Los desposorios de San José con la virgen } \\
\text { Maria }\end{array}$ & Soneto & Español & "Desponsata MARIA...JOSEPH" \\
\hline 3 & $\begin{array}{l}\text { Un vidrio plano transparente y dos candelas } \\
\text { encendidas, con la frente en candeleros de oro }\end{array}$ & Soneto & Español & "Duplicata que imago est" \\
\hline 4 & $\begin{array}{l}\text { Judith sacada por un ángel de la tienda de } \\
\text { Halofernes con su cabeza }\end{array}$ & Soneto & Español & $\begin{array}{l}\text { "Angelus Domini custodivit me; et sine } \\
\text { pollutione peccati revocavit me" }\end{array}$ \\
\hline 5 & $\begin{array}{l}\text { El arcángel San Rafael instruyendo a Tobías en } \\
\text { cómo debia ser casto con su esposa }\end{array}$ & Soneto & Español & $\begin{array}{l}\text { "Continens esto ab ea..., et nil aliud, } \\
\text { nisi orationibus vacabis" }\end{array}$ \\
\hline 6 & Impresor de estampas trabajando en su tórculo & Soneto & Español & "Imago saepius occurrens" \\
\hline 7 & $\begin{array}{l}\text { Madre perla o concha nácar cerrada, sobre las } \\
\text { aguas del mar }\end{array}$ & Soneto & Español & "Pretiosiora latent" \\
\hline 8 & $\begin{array}{l}\text { Farol de cristal, guardando en su seno una luz } \\
\text { y defendiéndola de muchos vientos }\end{array}$ & Epigrama & Latino & "Immota manet" \\
\hline 9 & $\begin{array}{l}\text { Un peñasco en medio del mar, azotado de } \\
\text { muchas olas }\end{array}$ & Soneto & Español & "Se mole tenet" \\
\hline 10 & Un espejo que recibe los rayos del Sol & Soneto & Español & "Unam faciemus utramque" \\
\hline 11 & $\begin{array}{l}\text { Dafne quien, huyendo enamorado de Apolo, se } \\
\text { convirtió en laurel para que conservara su } \\
\text { virginidad }\end{array}$ & Epigrama & Latino & $\begin{array}{l}\text { "Cui laurus aeternos honores peperit } \\
\text { triumpho" }\end{array}$ \\
\hline 12 & $\begin{array}{l}\text { EI Sol cuyos rayos pasan por las nubes y dan a } \\
\text { la tierra, que por un lado se enciende y por otro } \\
\text { está lleno de cerdos }\end{array}$ & Soneto & Español & "Non violabile vestrum Numen" \\
\hline 13 & $\begin{array}{l}\text { Un Sol amaneciendo y apagando con sus } \\
\text { esplendores los de la estrella de Venus, el } \\
\text { lucero }\end{array}$ & $\begin{array}{l}\text { Poema en } \\
\text { endecasílabos } \\
\text { y heptasílabos }\end{array}$ & Español & "Nuda recede Venus" \\
\hline 14 & Un mar en que se copia toda la parte del cielo & Soneto & Español & "Quantum instar in ipso est!" \\
\hline 15 & $\begin{array}{l}\text { Un sol llenando de rayos el globo celeste y el } \\
\text { globo terráqueo }\end{array}$ & Elegía & Latino & "Utroque magnus in orbe" \\
\hline 16 & La esfera armilar & Soneto & Español & "Non inferiora secutus" \\
\hline 17 & $\begin{array}{l}\text { Un monte incendiado por un rayo, que se } \\
\text { desprende de una nube }\end{array}$ & Epigrama & Latino & "Fulgor ibi ad Coelum se tollit" \\
\hline 18 & $\begin{array}{l}\text { Volcán de fuego reventado en la cima de un } \\
\text { monte }\end{array}$ & Epigrama & Latino & "Flamma propiore calesco" \\
\hline 19 & $\begin{array}{l}\text { Árboles pequeños que aún combatidos por } \\
\text { huracanes perseveran ilesos; los altos son } \\
\text { abatidos }\end{array}$ & Soneto & Español & "Feriunt que summos" \\
\hline 20 & $\begin{array}{l}\text { Un farol de cristal con una luz dentro y } \\
\text { cubierto con un pabellón }\end{array}$ & Oda & Latina & "Exhausta pericula terrae" \\
\hline 21 & $\begin{array}{l}\text { Garza blanca levantándose del suelo, antes que } \\
\text { dispare un cazador que le apunta }\end{array}$ & Carmen & Latino & "Effugere est triumphus" \\
\hline 22 & $\begin{array}{l}\text { Ulises atado al palo mayor del navío, antes de } \\
\text { enfrentar a las sirenas }\end{array}$ & Soneto & Español & "Frusta exercent cantus" \\
\hline 23 & Una hoguera & Epigrama & Latino & "Vitio caret, et sine labe" \\
\hline 24 & $\begin{array}{l}\text { La estatua de Astrea con resplandores de oro, } \\
\text { colocada en la faja del Zodiaco bajo el signo } \\
\text { de Virgo }\end{array}$ & Epigrama & Latino & "Tempora... aurati bis radij cingunt" \\
\hline 25 & El heliotropo mirando al sol & Soneto & Español & "Sequor, et qúa ducitis adsusm" \\
\hline 26 & Panales de abeja y un enjambre & Elegía & Latina & $\begin{array}{l}\text { "Foecundus erit, quod mirum in virgine, } \\
\text { partus" }\end{array}$ \\
\hline 27 & $\begin{array}{l}\text { Una rosa con sus espinas cercadas en un jardín } \\
\text { con reja de hierro }\end{array}$ & Oda & Latina & "Praesidium, et dulce decus" \\
\hline 28 & $\begin{array}{l}\text { Un cielo con horizonte de día y un poco más } \\
\text { alto un lucero }\end{array}$ & Epigrama & Latino & "Extulit ossacrum Coelo" \\
\hline
\end{tabular}

Fig. 4. Tabla de emblemas en El sol en virgo..., cuadro de elaboración propia 


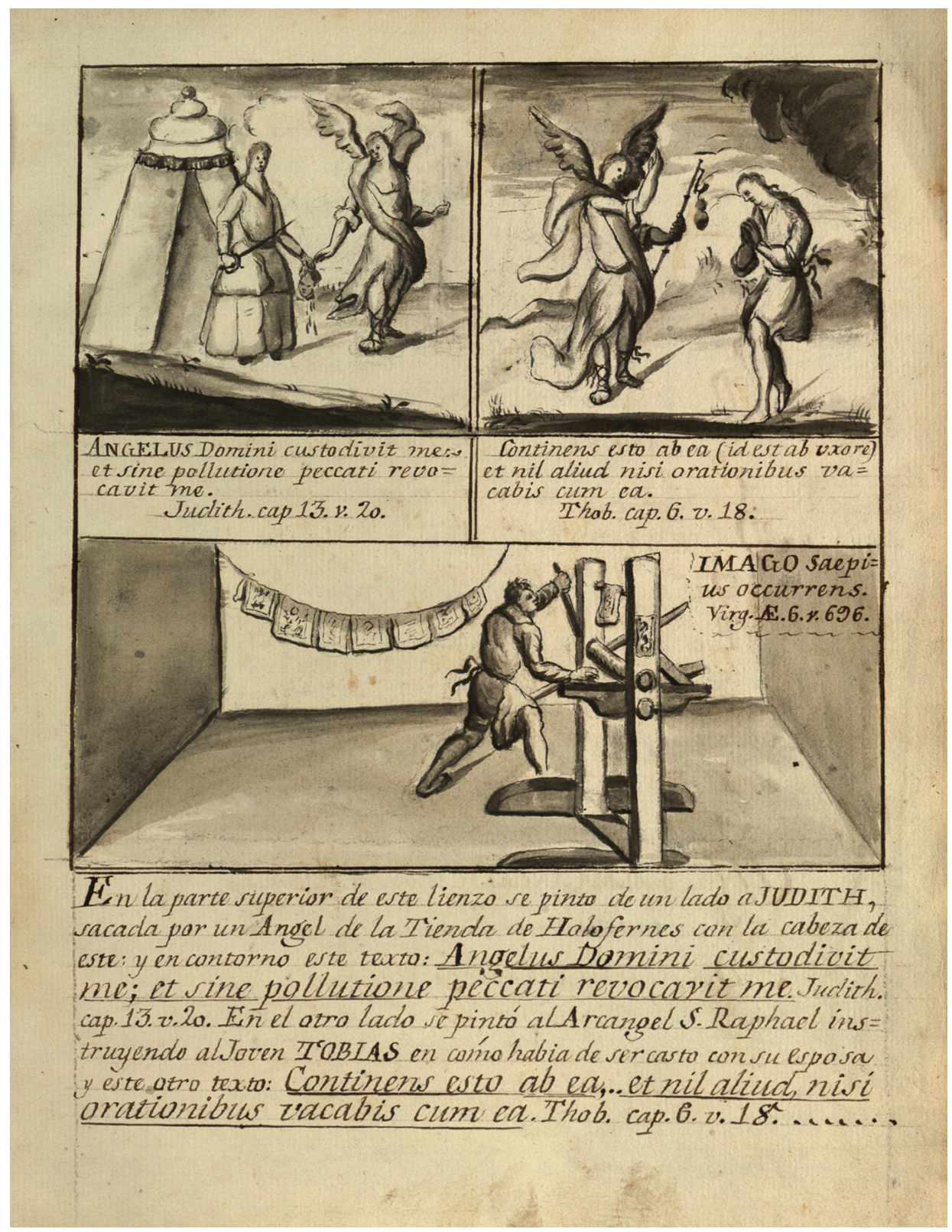

Fig. 5. Segundo emblema que aparece en $E l$ sol en virgo... a Sebastián de Aparicio, AHPSEM-BX4705 A6.556.5 1791, AHPSEM

Uno de los emblemas más interesantes es el de la alegoría con las sirenas y el barco de Ulises. Se trata de la referencia homérica de la prueba en donde Ulises se manda atar al navío, para no caer en la tentación del canto de las 
sirenas (Fig. 8). El emblema tiene referencia en la obra de Alciato, en el CXIV de la edición de Diego López, donde justo aparece la disposición de la nave del héroe de Ítaca, con los tres seres cantando con cítara, concha y voz. El sentido moral se fundamenta en la narrathio philoshopica del valenciano, continuada por alegoría en el emblema in del David Pecador... por Antonio de Lorea. En ambos, se coincide en la historia como ejemplo del hombre prudente y sabio, significado por Ulises, quien no hace caso de los vicios, transfigurados en las sirenas: «Poco importa el canto de las sirenas, como el hombre no quera dar oídos a sus acentos».$^{36}$ Antes, persigue la virtud, pues «soy columna que sujeto este edificio».

Tal es el sentido moral que encierra el emblema dedicado al beato. La pictura reproduce los motivos de los emblemistas referidos. En el mote, «Frustra exercent cantus» retomado de Geórgicas de Virgilio, se hace la sentencia del hombre sabio que no cede al canto. La suscriptio indica la alegoría entre fray Sebastián de Aparicio y Ulises, como arquetipos de la virtud, el valor, la prudencia y la defensa de la nave:
¿Para qué por tu mano te has atado
con una cuerda a un Árbol temeroso;
si golfos de peligros victorioso,
ya peleando, ya huyendo has navegado?
Si tu valor está bien enseñado
a triunfar de un incendio escandaloso.
¿Cómo ya desconfía de ti medroso,
y a los ojos, y oídos te has tapado?
Nunca más cuerdo Ulises ni valiente;
pues volando en la Nave de la vida
es por fin el salvarse contingente.
Cante en el Siglo turba fementida:
que en esa Nave tu intención prudente
va dos veces segura, y defendida. ${ }^{37}$

De esta manera, el soneto sostiene cómo el siglo y sus pesares son también otro canto de sirenas. Aunque, sobre la nave, según el verso, «va dos veces segura y defendida» en la presencia implícita del beato. Con ello, la idea de la pureza virginal, fuera de vicios.

36. Antonio de Lorea: David Pecador..., Madrid: Imprenta del Reyno por Francisco Sanz, 1674, p. 42; y Diego López: Declaración magistral de los emblemas de Alciato...: Nájera, Imprenta de Juan de Mongastón, 1615, pp. 285v-288r.

37. El sol en virgo..., p. sn. 


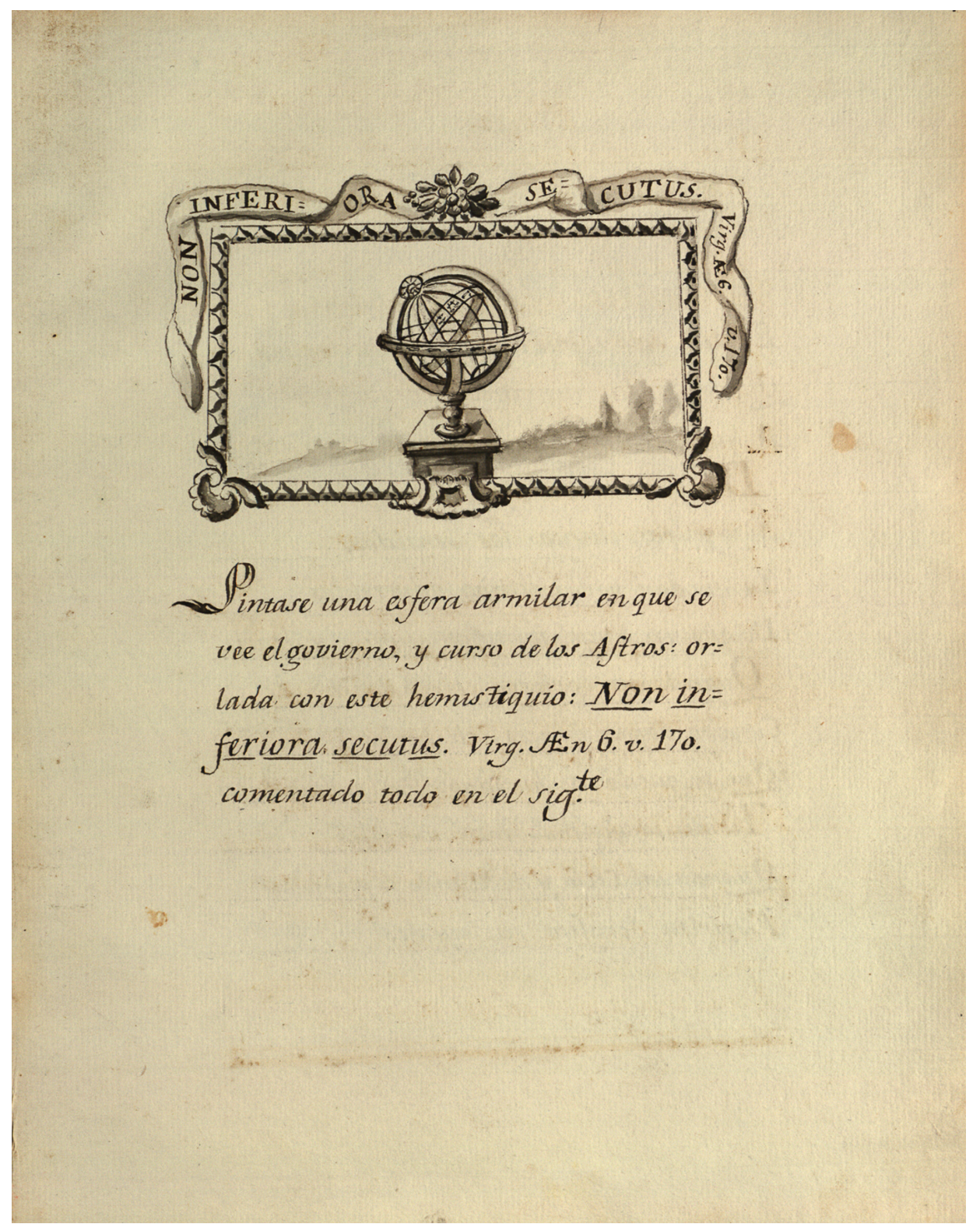

Fig. 6. Emblema de la esfera armilar a Sebastián de Aparicio, AнPSEм-вх4705 A6.556.5 1791, AHPSEM 


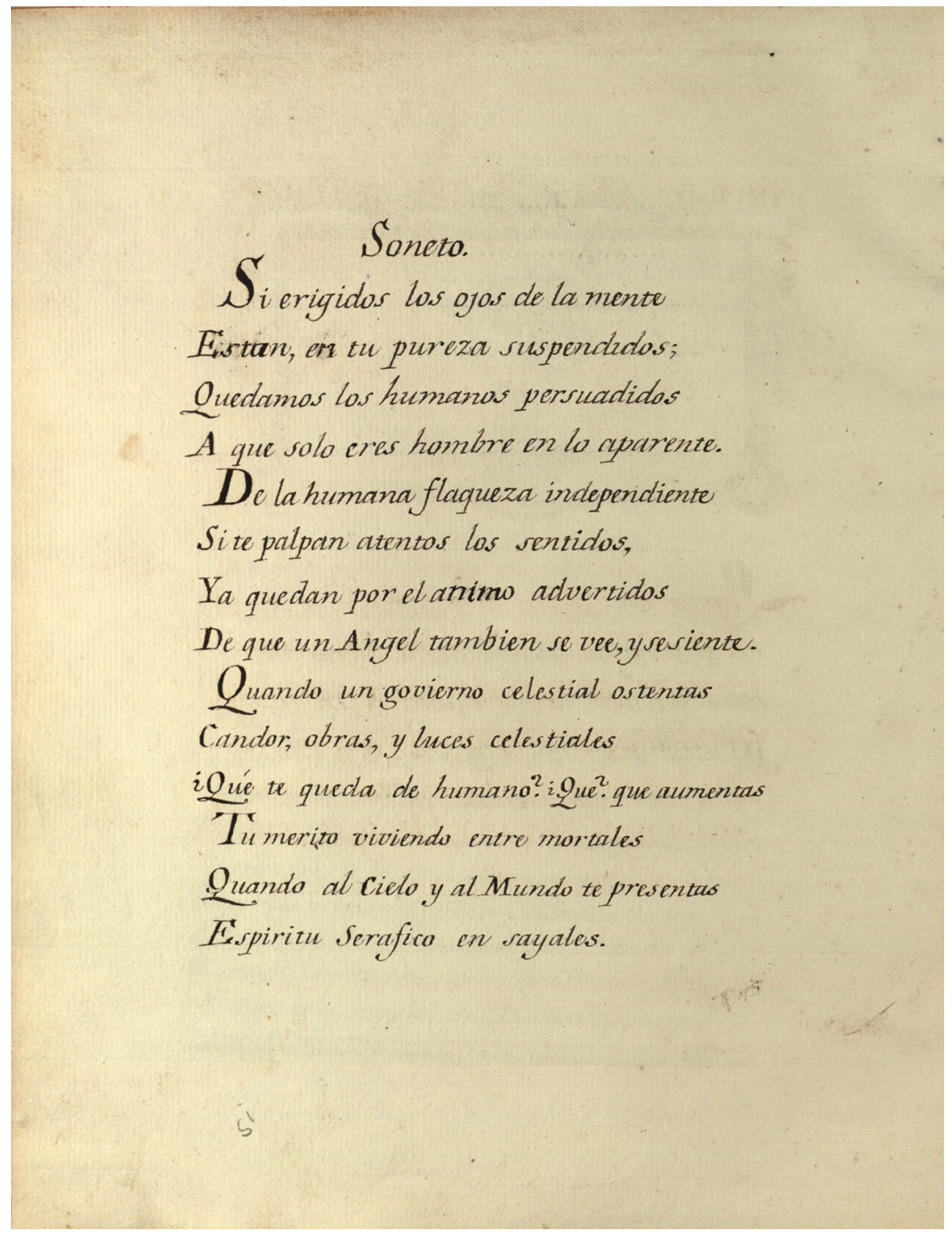

Fig. 7. Poema del emblema de la esfera armilar a Sebastián de Aparicio, AHPSEM-BX4705 A6.556.5 1791, AHPSEM 
Es menester destacar el sentido astrológico que cuenta el testimonio. El tipo iconográfico de todo el conjunto sitúa al sol en el signo de Virgo y con la alegoría del beato. De allí, se desprenden una serie de emblemas de características solares y con atributos de pureza y castidad. Está, por supuesto, la pictura del astro mayor llenando de luces a la tierra, de una larga tradición con referencias como por ejemplo el emblema XIx de L. Anneo Seneca... ${ }^{38} \mathrm{de}$ Juan Baños de Velasco, el de Juan de Borja o el propio Diego de Saavedra de Fajardo, ${ }^{39}$ aunque en este caso en un sentido de virginidad. Otro emblema es de un sol proyectando sus rayos en un espejo, quien refleja con mayor intensidad su imagen; emblema que puede rastrearse en el emblema CLXXI de Juan de Borja, con el enclave para el beato de amor divino en el cielo. ${ }^{40}$ Está también el sol con los heliotropos, con la referencia a Juan de Covarrubias, ${ }^{41}$ donde mientras que en los Emblemas Morales... se argumenta la caída de la gracia en la oscuridad, en la dedicada al fraile se incide que, a pesar de vivir entre mortales, su juicio y virtud prevalecieron.

Por su contenido y construcción, recálquense los siguientes emblemas solares en el manuscrito: la esfera armilar (Fig. 6 y Fig. 7), Dafne y la pureza (Fig. 9), así como el de Astrea (Fig. 10). El primero referido se trata en su pictura del instrumento cosmográfico «del que se ve el gobierno de los astros». De mote lleva el hemistiquio Non inferiora secutus de Virgilio y un soneto de suscriptio. El contenido emblemático respecto a la astrología tuvo un interesante traspaso de sentidos, siendo los primeros de carácter negativo, como sucede en los emblemas del astrólogo de Alciato o bien en Covarrubias en su emblema XLIX de la devoración del astrólogo Asdetarión por los perros o el XCVII del estudio de la astrología judiciaria que por pictura llevaba una esfera celeste sostenida por una mano. Sin embargo, el estudio de los astros cambió de sentido, ${ }^{42}$ que en cierta medida se señalaba en la narrathio philosophica de Covarrubias: permitida en las causas naturales, pero no de la dependencia del libre albedrío o la voluntad de divina.

38. JuAn Baños de Velasco: L’Aneno Seneca..., Madrid: Impreso por Mateo de Espinoza y Arteaga, 1670, p. 305.

39. Diego Sanedra de Fajardo: Idea de un Príncipe Político Cristiano..., Amberes: Casa de Ieronimo y Iuan Bapt. Verdussen, 1655. 379.

40. JUAn DE BorJa: Empresas Morales..., Bruselas: Impreso por Francisco Foppens, 1680, pp-378-

41. Sebastián de Covarrubias Horozco: Emblemas Morales..., Madrid: Imprenta de Luis Sánchez, 1610, p. 112.

42. Véase: Carlo Ginzburg: Mitos, emblemas, indicios. Morfología e historia, Barcelona: Editorial Gedisa, S.A., 1999; Víctor Mínguez: Los reyes solares: Iconografía astral de la monarquía hispánica, Castelló de la Plana: Universitat Jaume I, 2001; o SALVAdor LiRa: Protocolos, ceremoniales y símbolos en los Actos de Real Sucesión patrocinados por la Real Audiencia de México durante la transición dinástica (16661725), Zacatecas: Tesis de Doctorado en Estudios Novohispanos - UAZ, 2020, específicamente el apartado «De Revolutionibus Orbium Colestium: los emblemas astrológicos en la transición», pp. 332-345. 


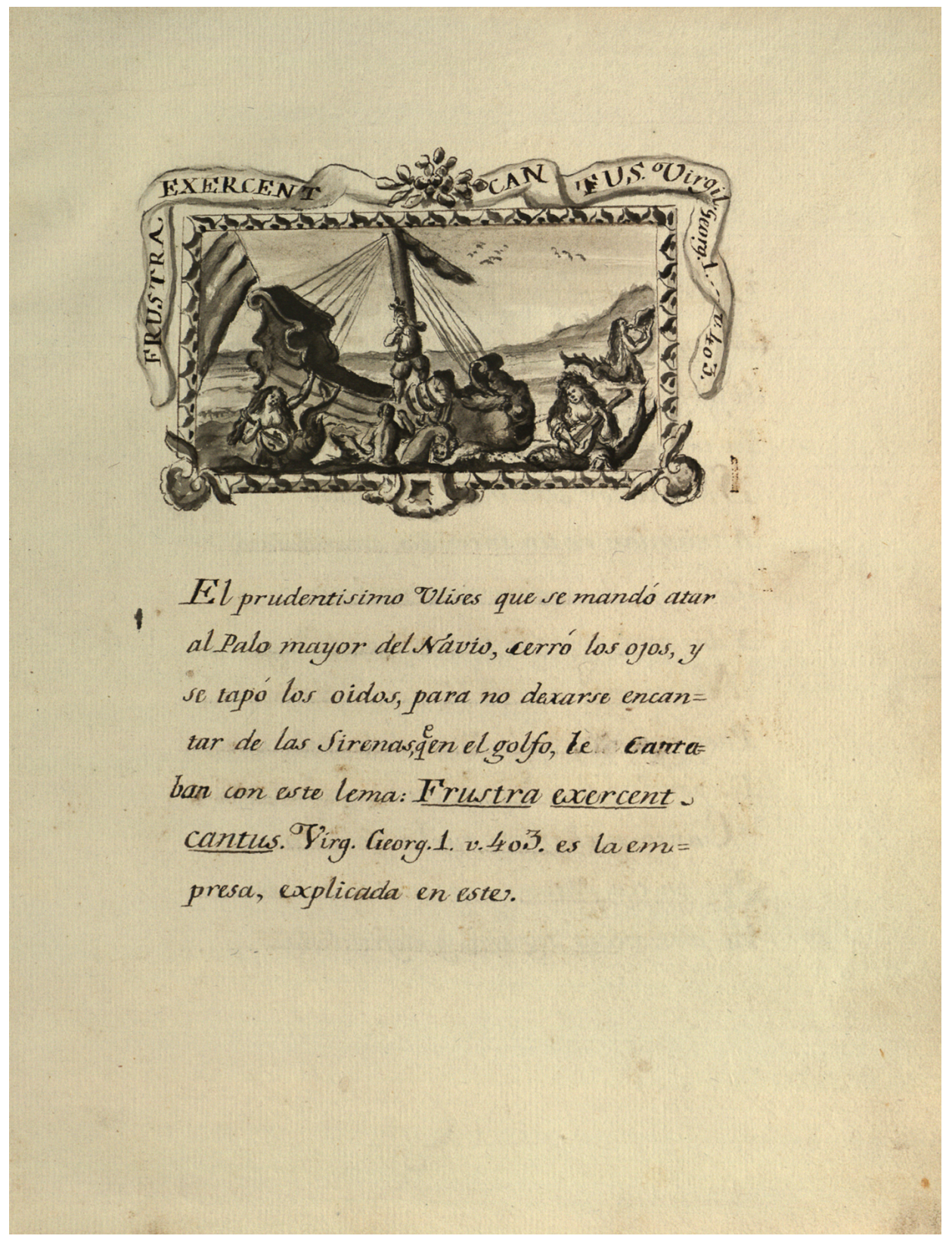

Fig. 8. Emblema de la nave de Ulises a Sebastián de Aparicio, AHPsem-Bx4705 A6.556.5 1791, AHPSEM 
Cabe decir que son pocos los ejemplos de la esfera armilar como pictura. Dentro de las obras con emblemas en Nueva España, aparece la esfera armilar en dos emblemas: uno con el emblema del astrólogo estudiando al sol en las exequias a Carlos II y otra en Urania como atributo en las exequias a Luis I. ${ }^{43}$ En ambos, el sentido de la lectura de las estrellas es para reafirmar la idea y grandeza de ambos monarcas fallecidos, sin mácula, cuales eternos soles. El mismo sentido, aunque de carácter lunar, se encuentra en la obra de Francisco Xavier Dornn, fundamentalmente en «Mater Purissima». ${ }^{44}$ En tal, los astrólogos con el telescopio y en la medición de instrumentos como la esfera armilar, al centro, o el compás, observan a la virgen «toda pulcra, sin mácula». La suscriptio y el mote al beato confirman la idea de que en la apariencia solo es un hombre, aunque su pureza, bien mirado entre astros, cielo y tierra, lo hacen un «Espíritu Seráfico en sayales».

El emblema de Dafne y la pureza (Fig. 9), por su parte, tiene como referencia el de Hernando de Soto. En los Emblemas moralizados..., ${ }^{45}$ en el Ix aparece Apolo con su cara en forma de sol y con vestimenta del siglo XVI, cantando a tres figuras «Dafne», que se han convertido en árboles de laurel. El sentido del emblema es que en este tiempo muchos se llaman poetas, aunque los dignos son aquellos que combinan arte y favor divino. En el emblema al beato, Apolo aparece con arco y con vestimenta más antigua, con la cabeza iluminada. Dafne es aquí un solo árbol, en donde tanto en la descripción como en la suscriptio y mote, se destacan la conservación intacta de la virginidad en favor divino, con lo que se hace alusión a la castidad de fray Sebastián de Aparicio aún contrayendo nupcias.

El emblema de Astrea (Fig. 10), finalmente, apunta a la justicia en los tiempos romanos, según la descripción. Se alude, por un lado, a Ripa por justicia divina o recta, quien sostiene la balanza y la espada, con una paloma en lo alto cual Espíritu Santo de vínculo. ${ }^{46}$ El concepto se refuerza en la cinta zodiacal en Virgo, con la referencia de Redeliu y Dornn en «Regina Apostolorum». En este caso, en la cintilla zodiacal aparece Sebastián de Aparicio, en la misma forma de la portada del manuscrito, reforzando el sentido del tipo iconográfico de todo el conjunto del aparato y sus emblemas. El sentido del emblema recalca la justicia y la virtud de la castidad.

43. Agustín de Mora: El sol eclypsado..., Ciudad de México: Imprenta de Joseph Guillena Carrascoso, 1701 y José de Villerías: El llanto de las estrellas..., Ciudad de México: Imprenta de Jospeh Bernanrdo de Hogal, 1725.

44. No hay que olvidar que su hermano, Rafael Larrañaga, realizó una traducción de las letanías para este tiempo. Véase: Fátima de LiRa URAnday: Estudio de la versión de las Letanías lauretanas de Francisco Xavier Dornn por Francisco Rafael Larrañaga, en la traducción de 1789 a Úrsula Garcez y Eguía, Zacatecas: Tesis de Doctorado en Estudios Novohispanos (en proceso)-uAZ, 2021.

45. Hernando de Soto: Emblemas moralizados..., Madrid: Imprenta de los herederos de Juan Íñiguez de Lequerica, 1599.

46. Cesare Ripa: Iconología II, Madrid: Akal Ediciones, 1996, p. 9. 


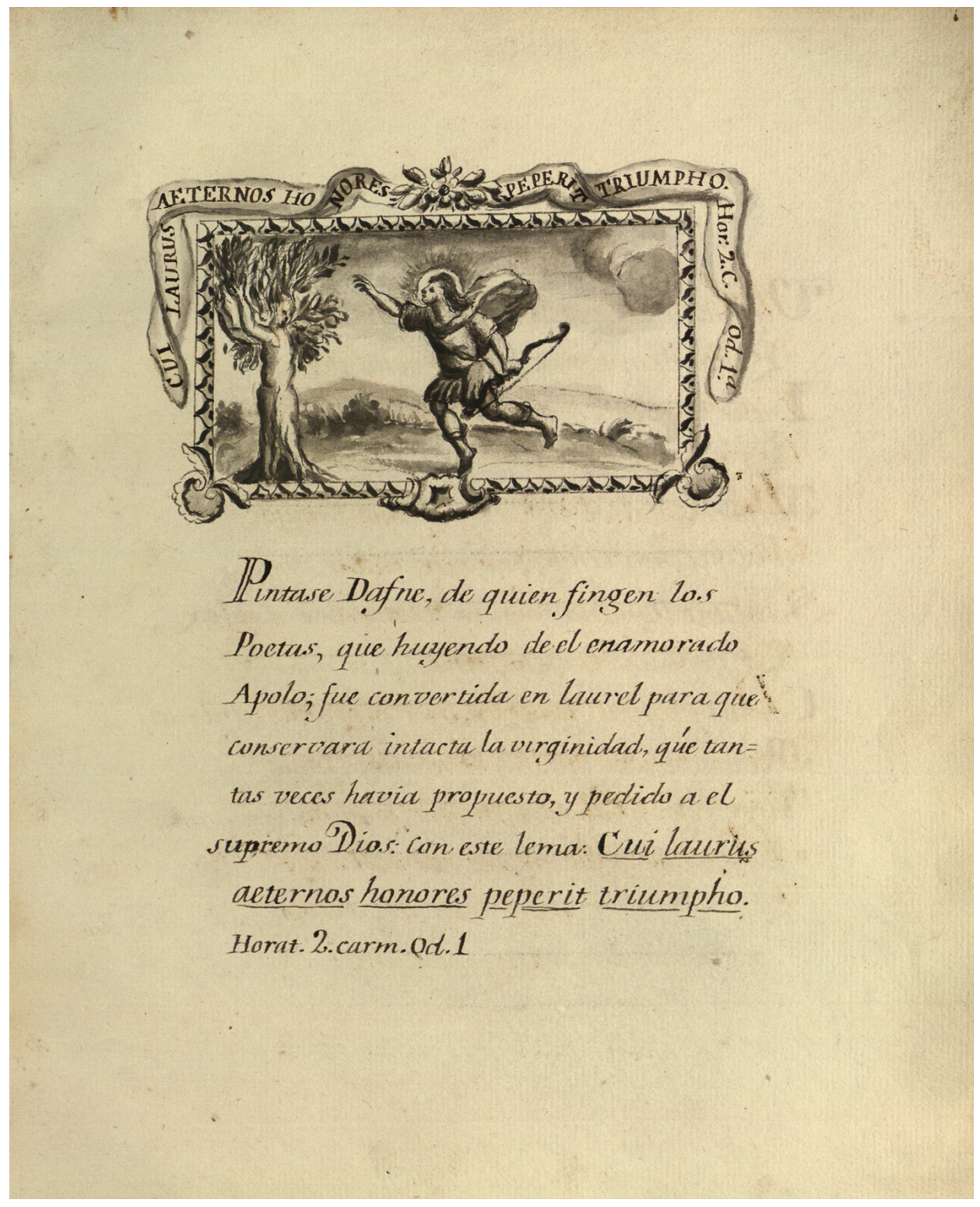

Fig. 9. Emblema de Dafne y Apolo a Sebastián de Aparicio, Aнpsem-Bx4705 A6.556.5 1791, AHPSEM

A manera de conclusión, las fiestas de beatificación a fray Sebastián de Aparicio en la ciudad de México mostraron una serie de condicionantes que, en perspectiva, no responden ni a sus atributos construidos durante el siglo XVII y XVIII, ni a las propuestas en el espacio poblano. En términos rituales, 
las divergencias se dieron por parte de una razón de preeminencia. La ausencia de la Real Audiencia condicionó la también ausencia del cabildo de la ciudad, por lo que es muy probable que tales fastos no tuvieran el impacto a lo largo y ancho de la América Septentrional, a pesar de ser un momento o la proposición de identidad que pudiera posibilitar la exaltación novohispana. Esto toma mayor interés, si se tiene en cuenta que no se siguió con un apoyo para el proceso de santificación.

Por otro lado, a pesar de la magnífica propuesta emblemática en El Sol en Virgo..., no se imprimieron las relaciones de beatificación. Es probable que se deba justamente por el no apoyo económico posterior a las fiestas o bien porque esto implicaría un desajuste de espacios que, por ejemplo, se sugiere en la oración por Agustín de Quintela y la dignidad mayor al obispo poblano por encima de otras figuras en la capital novohispana.

Muchos elementos están todavía por estudiarse. Ya se ha dicho que aún está pendiente la revisión de las representaciones de fray Sebastián de Aparicio fuera del espacio poblano; así como una edición crítica de El Sol en Virgo... con un estudio pormenorizado de los emblemas y poemas. Con ello, la apertura y repaso de representaciones artísticas -antes, durante y después de su proceso de beatificación- con diversos códigos, tales como el siguiente poema «jocoserio»:

\author{
Llegó a la portería de Santa Clara \\ por APARICIO un Payo preguntando; \\ y una Monja le respondió mofando: \\ mejor fuera que en Roma lo buscara. \\ No fuera mucho (él dijo) que lo hallara \\ en Roma, o con Ustedes habitando: \\ algún día vendrá de allá triunfando \\ y aquí querrán ponerlo su Altar y Ara. \\ Con él, Maternidades melindrosas, \\ estuvieran muy bien, y él estuviera: \\ pues quien guardó en batallas peligrosas \\ su Castidad que no se le perdiera, \\ y quien puras guardó sus dos Esposas, \\ mejor con las de Cristo procediera. ${ }^{47}$
}

47. El sol en virgo..., p. sn. 


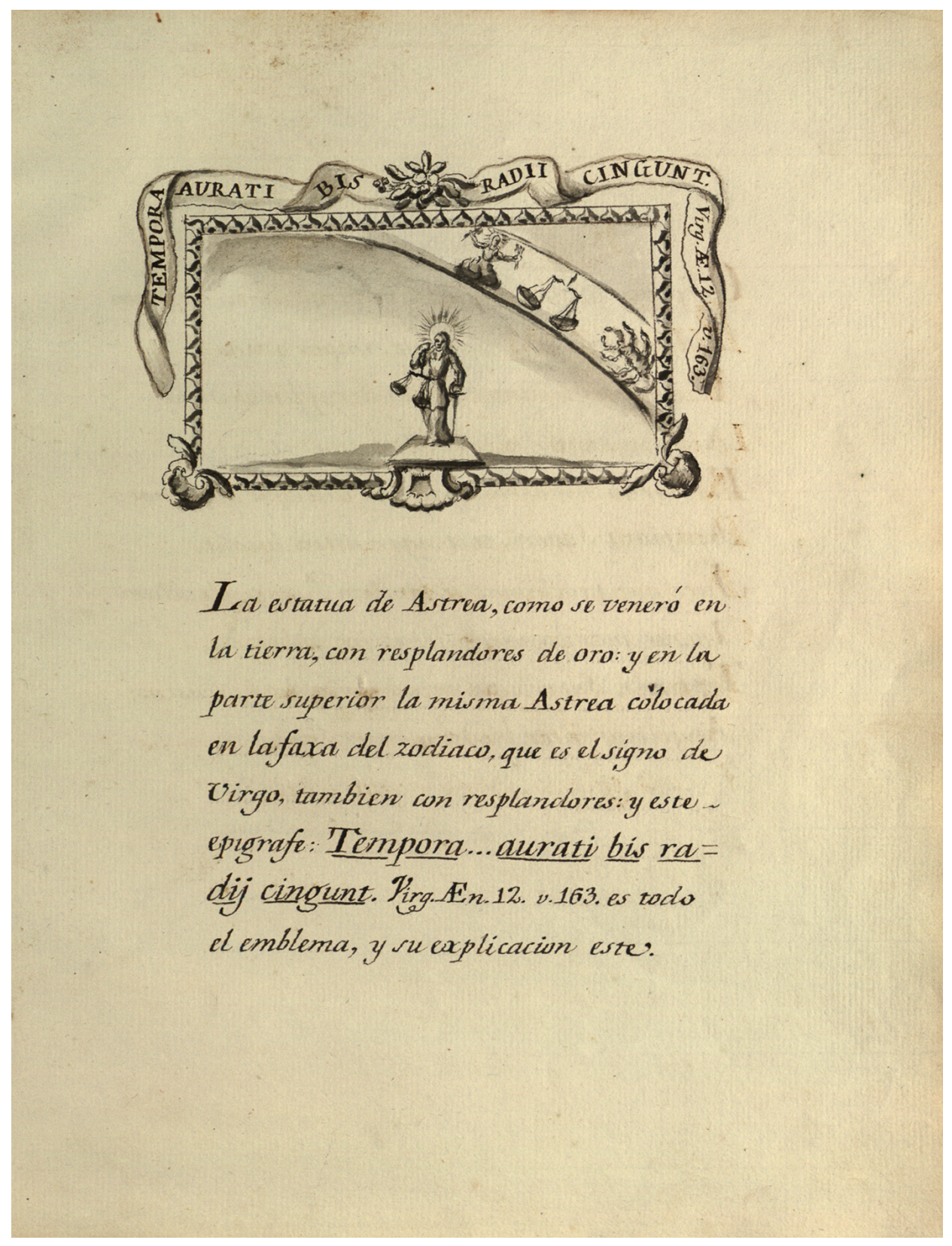

Fig. 10. Emblema de Astrea a Sebastián de Aparicio, AHPSEM-BX4705 A6.556.5 1791, AHPSEM 


\section{BibliografíA}

Actas de Cabildo, Libro 17, AHCM.

Aguado, Leonardo: Vida del beato Sebastián de Aparicio, Secretaría del Arzobispado de México, Ciudad de México, 1947.

Ayuntamiento, Patronato, 3604, exp. 22, AHCM.

Báez Hernández, Monserrat Andrea: De los despojos corporales a la reliquia y su imagen: el caso angelopolitano del beato Sebastián de Aparicio, Ciudad de México: Tesis de Maestría en Historia del Arte - UNAM, 2017.

-: «El proceso apostólico de Sebastián de Aparicio patrono no jurado de la ciudad de los Ángeles», Cuextlaxcoapan Revista del Centro Histórico de la ciudad de Puebla, año 4, n. 14, verano 2018, pp. 16-21.

Baños de Velasco, JuAn: L'Aneno Seneca..., Madrid: Impreso por Mateo de Espinoza y Arteaga, 1670.

BorJA, JUAN DE: Empresas Morales..., Bruselas: Impreso por Francisco Foppens, 1680.

Breve relación de las funciones..., Ciudad de México, Imprenta de Felipe de Zúñiga y Ontiveros, 1790.

Carmona, Joseph: Panegírico sagrado del B. Sebastián de Aparicio..., Puebla de los Ángeles: Oficina del Real Seminario Palafoxiano, 1792.

Chiva Beltrán, Juan: El triunfo del virrey. Glorias novohispanas: origen, apogeo y ocaso de la entrada virreinal, Castellón de la Plana: Universitat Jaume I, 2012.

Covarrubias, Sebastián de: Emblemas Morales..., Madrid: Imprenta de Luis Sánchez, 1610.

Cuenta y razón de todo lo gastado por el padre Galindo en las fiestas de la beatificación de fray Sebastián de Aparicio realizadas en Puebla y México, Clasificación Local: 126/1641.5, BNM.

Dornn, Francisco Xavier: Letanía Lauretana..., Valencia: Imprenta de la viuda de Joseph de Orga, 1768.

Eguiara Eguren, Juan José: Bibliotheca mexicana..., Ciudad de México: Ex Nova Typographia in Aedibus Athoris editioni ajusdem Bibliothecae Destinata, 1755.

El sol en virgo..., AHPSEM-BX4705 A6.556.5 1791, AHPSEM.

Garone Granvier, Marina: «Imprenta y libro antiguo. Consideraciones para el estudio material de la literatura novohispana», en JEssiCA C. LoCKe, Ana Castaño y Jorge Gutiérrez Reyna (coords.): Historia de las literaturas en México. Siglos XVI al XVIII, Tomo 1: El primer siglo de las letras novohispanas (1519-1624), Ciudad de México: UnAM, 2021, pp. 3-40.

Gazeta de México, en: http://www.hndm.unam.mx/index.php/es/.

Ginzburg, Carlo: Mitos, emblemas, indicios. Morfología e historia, Barcelona: Editorial Gedisa, S.A., 1999. 
Isidoro de SAn Miguel: Paraíso cultivado..., Nápoles: Estampería de Juan Vernuccio y Nicolas Layno, 1695.

Lira, Salvador: Protocolos, ceremoniales y símbolos en los Actos de Real Sucesión patrocinados por la Real Audiencia de México durante la transición dinástica (1666-1725), Zacatecas: Tesis de Doctorado en Estudios Novohispanos-UAZ, 2020.

-: «De la alegoría a la virtud: exequias reales a Carlos III en la Nueva España», Revista Dieciocho, número 44, fall 2, 2021, pp. 279- 308.

lira, Salvador y Terán Elizondo, María Isabel: «Non fecit taliter omni nationi: los emblemas de la identidad criolla novohispana en expresiones de lealtad a la monarquía de los Austrias menores», en JosÉ Julio García Arranz y Pedro Germano Leal (eds.): Jeroglíficos en la Edad Moderna. Nuevas aproximaciones a un fenómeno intercultural, Coruña: SIELAE, 2020, pp. 331-368.

-: «Las juras a Carlos IV en la Nueva España y el proyecto de Ignacio de Castera», en prensa, 2021.

Lira URANDAy, Fátima DE: Estudio de la versión de las Letanías lauretanas de Francisco Xavier Dornn por Francisco Rafael Larrañaga, en la traducción de 1789 a Úrsula Garcez y Eguía, Zacatecas: Tesis de Doctorado en Estudios Novohispanos (en proceso)-UAZ, 2021.

LoCKE, JessiCA C.: Es grande el poder de la poesía, Madrid: IberoamericanaVervuert, 2019.

López, Diego: Declaración magistral de los emblemas de Alciato...: Nájera, Imprenta de Juan de Mongastón, 1615.

Lorea, Antonio De: David Pecador..., Madrid: Imprenta del Reyno por Francisco Sanz, 1674.

Mariani, Paolo: Vita, e miracoli del venerabile servo di Dio fr. Sebastiano d'Apparisio..., Roma: Marc'Antonio \& Orazio Campana, 1696.

Maza, Francisco de la: Las piras funerarias en la Historia y en el Arte de México. Grabados, Litografías y Documentos del siglo XVI al XIX, Ciudad de México: UnAM-Anales del Instituto de Investigaciones Estéticas, 1946

Medina, Baltasar de: Crónica de la Santa Provincia de San Diego..., Ciudad de México: Juan de Ribera Impresor, 1682.

«Memoria de los diseños por algunos pintores...», 1623, Clasificación 124/1623.4, BNM.

Mínguez, Víctor: Los reyes distantes: imágenes del poder en el México virreinal. Castelló de la Plana: Universitat Jaume I, 1995.

-: Los reyes solares: Iconografía astral de la monarquía hispánica, Castelló de la Plana: Universitat Jaume I, 2001

Mínguez, Víctor; Juan Chiva Beltrán; Pablo González Tornel y INMACULADA Rodríguez Moya (coords.): La fiesta barroca. Los virreinatos americanos (1560-1808), Castelló de la Plana: Publicacions de la Universitat Jaume I, 2012 
Mora, Agustín de: El sol eclipsado..., Ciudad de México: Imprenta de Guillena Carrascoso, 1701.

Obras de elocuencia y poesía premiadas por la Real Universidad de México..., Ciudad de México: Imprenta de Felipe de Zúniga y Ontiveros, 1791.

Plancarte, fray Joseph: Rezo devoto..., Ciudad de México: Imprenta de Mariano Zúñiga y Ontiveros, 1925.

Plumbensi, Nicolás: Opusculum vitae..., Roma: Ex Oficina Reverendae Camerae Apostolicae, 1696.

Quintela, Agustín De: La sencillez..., Ciudad de México: Imprenta de Mariano Joseph de Zúñiga y Ontiveros, 1791.

Ragon, Pierre, «Sebastián de Aparicio: un santo mediterráneo en el altiplano mexicano», Estudios de Historia Novohispana, año 36, volumen 60, enero-junio 2019, pp. 17-45.

Reales exequias celebradas en la santa iglesia catedral..., Ciudad de México: Imprenta de Felipe de Zúñiga y Ontiveros, 1790.

Redelio, A. C.: Elogia Mariana..., Augsburg: Martino Engelbrecht Chalcographo, 1732.

Ripa, CesARE: Iconología II, Madrid: Akal Ediciones, 1996.

SaAvedra de Fajardo, Diego: Idea de un Príncipe Político Cristiano..., Amberes: Casa de Ieronimo y Iuan Bapt. Verdussen, 1655.

Salazar Andreu, Juan Pablo: «Algunos aspectos políticos y jurídicos del obispo de Puebla Salvador Biempica y Sotomayor (1790-1802)», Anuario Mexicano de Historia del Derecho, vol. xviI, 2005, p. 83-96.

SARIÑANA, Isidro De: Llanto del Occidente..., Ciudad de México: Imprenta de la Viuda de Calderón, 1666.

Soto, Hernando DE: Emblemas moralizados..., Madrid: Imprenta de los herederos de Juan Íñiguez de Lequerica, 1599.

Terán Elizondo, María Isabel: Orígenes de la crítica literaria en México: La polémica entre Alzate y Larrañaga, Ciudad de México: UAZ- 1 Colegio de Michoacán, 2001.

-: Dos poetas admiradores de Virgilio. La obra literaria de Bruno Francisco y José Rafael Larrañaga, Ciudad de México: Factoría Ediciones - UAZ - La Serpiente Emplumada, 2021.

The life of the blessed Sebastian of Apparizio..., London: Thomas Richardson and Son, 1848.

Trujillo Diosdado, José Manuel: Ritual político y emblemática novohispana. Representaciones del héroe en la entrada triunfal virreinal, Querétaro: Tesis de Maestría en Estudios Históricos, UAQ, 2017.

VILleríAs, José DE: El llanto de las estrellas..., Ciudad de México: Imprenta de Joseph Bernardo de Hogal, 1725

Ximénez, Mateo: Compendio della vita del Beato Sebastiano D’Apparizio..., Roma: Estampería Salomoni, 1789. 